\title{
Environmental hazard of polypropylene microplastics from disposable medical masks: acute toxicity towards Daphnia magna and current knowledge on other polypropylene microplastics
}

Anita Jemec Kokalj ${ }^{*}$ (D, Andraž Dolar ${ }^{1}$, Damjana Drobne ${ }^{1}$, Marjan Marinšek², Matej Dolenec ${ }^{3}$, Luka Škrlep $^{4}$, Gregor Strmljann ${ }^{4}$ Branka Mušič ${ }^{4}$ and Andrijana Sever Škapin ${ }^{4}$

\begin{abstract}
The COVID-19 pandemic has increased the use of disposable plastics, including medical masks, which have become a necessity in our daily lives. As these are often improperly disposed of, they represent an important potential source of microplastics in the environment. We prepared microplastics from polypropylene medical masks and characterised their size, shape, organic chemical leaching, and acute toxicity to the planktonic crustacean Daphnia magna. The three layers of the masks were separately milled and characterised. Each of the inner frontal, middle filtering, and outer layers yielded different types of microplastics: fibres were obtained from the inner and outer layer, but irregular fragments from the middle layer. The shape of the obtained microplastics differed from the initial fibrous structure of the intact medical mask layers, which indicates that the material is deformed during cryomilling. The chemical compositions of plastics-associated chemicals also varied between the different layers. Typically, the inner layer contained more chemicals related to antimicrobial function and flavouring. The other two layers also contained antioxidants and their degradation products, plasticisers, cross-linking agents, antistatic agents, lubricants, and non-ionic surfactants. An acute study with D. magna showed that these microplastics do not cause immobility but do physically interact with the daphnids. Further long-term studies with these microplastics are needed using a suite of test organisms. Indeed, studies with other polypropylene microplastics have shown numerous adverse effects on other organisms at concentrations that have already been reported in the environment. Further efforts should be made to investigate the environmental hazards of polypropylene microplastics from medical masks and how to handle this new source of environmental burden.
\end{abstract}

Keywords: COVID-19 pandemic, Plastics-associated chemicals, Daphnia magna, Fibres, Fragments, Nanofibres, Polypropylene microplastics, Single-use plastic

\footnotetext{
* Correspondence: anita.jemec@bf.uni-lj.si

'Department of Biology, Biotechnical Faculty, University of Ljubljana, Večna

pot 111, Sl-1000 Ljubljana, Slovenia

Full list of author information is available at the end of the article
}

\section{Springer Open}

(c) The Author(s). 2021 Open Access This article is licensed under a Creative Commons Attribution 4.0 International License, which permits use, sharing, adaptation, distribution and reproduction in any medium or format, as long as you give appropriate credit to the original author(s) and the source, provide a link to the Creative Commons licence, and indicate if changes were made. The images or other third party material in this article are included in the article's Creative Commons licence, unless indicated otherwise in a credit line to the material. If material is not included in the article's Creative Commons licence and your intended use is not permitted by statutory regulation or exceeds the permitted use, you will need to obtain permission directly from the copyright holder. To view a copy of this licence, visit http://creativecommons.org/licenses/by/4.0/. 


\section{Introduction}

With the crisis of the global coronavirus pandemic (COVID-19), the consumption of single-use plastics, including personal protective equipment, has increased significantly. This has become essential to prevent the spread of infection among healthcare workers and the general public [1-3]. Among the protective equipment, disposable medical (face) masks (also called surgical masks) are most commonly used by the general public, as some governments have recommended or mandated their use indoors as well as outdoors [1].

The use of medical masks as an infection control measure was common in East and South-East Asia at the onset of the COVID-19 pandemic, and it then gained momentum in the rest of the world during 2020 and 2021 [4]. The production volume as well as the use of medical masks is already enormous, and is expected to continue to increase in the near future. For example, at the end of April 2020, China was producing about 450 million medical masks daily. Indeed, as the leading manufacturer, the annual production volume of medical masks in China increased from 5 billion in 2019 to 10 billion in 2020 [5].

There is a wide variety of medical masks on the market that are made of different plastics, such as polyurethane, polyacrylonite, polyester, polyethylene terephthalate and polypropylene. The last of these, polypropylene, remains by far the most common material and has a long history of use [6-8]. This was also confirmed by searching online medical devices catalogues (search term: surgical masks; Medical Expo, 2020), where all of the medical masks that indicated the polymer composition (about $20 \%$ of those available) were polypropylene. In addition, many companies online sell polypropylene as the raw material for making medical masks. Generally, medical masks consist of three main layers: the inner frontal layer, the middle filtering layer, and the outer layer, which is usually water repellent and coloured. The filter materials are produced by a 'non-woven' approach, which refers to the layers of the fibres as bonded together by physical entanglements or contact adhesion between the individual fibres $[9,10]$. This approach includes different processes, such as for melt-blown and spun-bond fabrics, each of which results in different final fibre diameters. The most commonly reported approach to produce the middle filter layer of the medical mask material is melt blowing, while the spun-bond process is used to produce the inner and outer layers of the masks [9].

The major environmental concern associated with the increasing use of disposable medical masks by the general public is poor waste management $[2,6,7]$. Although it was suggested recently that a possible route for waste management would be thermo-chemical conversion of disposable medical masks into valueadded products [11], improper disposal of masks in public spaces [2] and into the environment in general $[6,7]$, is widespread. This contributes to global plastics pollution, which has numerous negative impacts on the environment [12]. In addition, as identified recently, disposable medical masks might represent a significant new source of microplastics $[2,6,7,13,14]$.

Similar to other plastic items, once medical masks are disposed of into the natural environment, they undergo weathering processes, including ultraviolet radiation, temperature fluctuations, increased humidity, biodegradation, physical abrasion and chemical oxidation. Weathering affects the physicochemical properties of plastics, and eventually leads to their fragmentation into microplastics and nanoplastics [15-19]. The degradation of plastics is highly dependent on the polymer type and any chemical additives [20, 21]. Polypropylene, the material most commonly used in the medical mask production, is susceptible to photodegradation [14, 20, 22], heat [23] and atmospheric oxygen [24]. Polypropylene is excellent in terms of water resistance, but inferior in terms of weathering resistance. Moisture accelerates the oxidative degradation of polypropylene, and consequently its melting point and thermal decomposition temperature are lowered, and its mechanical properties deteriorate [25]. In the external environment, conditions can be even more severe, such as lower (acidic) pH due to acid rain, higher (alkaline) $\mathrm{pH}$ due to fertilization with nitrogen compounds and accelerated decomposition of plastics, and the presence of electrolytes, due to road salting or along coastal areas. A number of studies have shown that polypropylene is susceptible to outdoor weathering $[19,26]$, although it is not readily biodegradable [27]. To some extent, shedding and peeling of microfibres from medical masks is also likely to occur, as has been shown for polyester textiles that release fibres into water and air during household washing and drying, and during their regular use [28]. However, the release of fibres is highly dependent on the textile structure, as there will be less release for textiles with a compact woven structure [29]. There are already some estimations on the amount of microplastics released from medical masks $[13,14]$. Chen et al. [13] estimated the release of microplastics from 18 brands of medical masks into the water (shaking at $120 \mathrm{rpm}, 24 \mathrm{~h}$ ). In this way, from $159.80 \pm$ 46.14 to $222.17 \pm 98.79$ particles/medical mask was released when the masks were new, but the numbers increased significantly when the masks were already used $(1146.00 \pm 307.60$ to $1478.00 \pm 265.80$ particles/mask). Both fragments and fibres were found in water. The second study by Wang et al. [14] incubated the three layers of the medical mask separately in water with added quartz sand (shaking at $300 \mathrm{rpm}, 24 \mathrm{~h}$ ). The authors 
report that the release of microplastics depends on the UV weathering of the masks, addition of the sand as well as on the layer of the mask. They estimated that around 483,888 plastic particles could be released from one virgin disposable mask, and 1,566,560 particles from the weathered mask if the whole mask would disintegrate.

Over the past 15 years, tremendous research efforts have been made to understand the global occurrence, distribution and potential environmental hazards of microplastics and their associated chemicals [30, 31]. Research on the potential adverse effects of microplastics on organisms has been very intense over the past decade which has demonstrated physiological perturbations in organisms exposed to microplastics (e.g., alterations to behaviour, immune responses, energy allocation, life traits), and potential links to altered ecosystem function (for reviews see [32-34]).

The aim of this paper was to thoroughly characterise the microplastics obtained from commercially available polypropylene medical masks and to evaluate their acute toxicity to the planktonic crustacean Daphnia magna. The microplastics from the inner frontal, middle filtering, and outer layers of disposable medical masks were investigated separately in terms of their size, shape, organic chemical leaching and aquatic toxicity. We discuss the properties of polypropylene microplastics from medical masks in line with the literature reports on plasticsassociated chemicals in other polypropylene products. We provide an extensive overview of currently available ecotoxicity data for microplastics from other polypropylene-based products, as currently very limited data for microplastics from medical masks exist. Finally, we identify the knowledge gaps to guide further research in the field.

\section{Methods}

\section{Milling of medical masks to produce microplastics}

We produced microplastics from exemplary medical masks (sold as polypropylene, with three layers, the outer layer was blue) which were obtained from local supplier of medical protective equipment. The three layers were milled separately according to our established protocols [35]. Briefly, the material of each layer was separately cut with scissors into small pieces $(\sim 0.5$ $\mathrm{cm}^{2}$ ), which were placed in a milling bowl. This milling bowl was put into liquid nitrogen, and left frozen for 4 min. Then the samples were milled, following a 'quasicryo-milling' procedure, whereby instead using liquid nitrogen as the coolant for the cryo-milling, the liquid nitrogen was used to maintain the material frozen before milling. This was carried out with a horizontal homogeniser (Milli Mix 20; Domel, Slovenia) with milling balls (diameter, $25 \mathrm{~mm}$ ). The milling of the samples was performed at a horizontal frequency of $28 \mathrm{~Hz}$, for 2.5 min. After milling, the samples were sieved through a 250- $\mu \mathrm{m}$-pore sieve.

\section{Characterisation of microplastics Fourier-transform infrared spectroscopy}

To determine the main material used in the three layers of the medical masks, attenuated total reflection-Fourier-transform infrared spectroscopy (diamond crystal) was carried out (FTIR Spectrum Two spectrometer; PerkinElmer). The spectra were recorded from $400 \mathrm{~cm}^{-1}$ to $4000 \mathrm{~cm}^{-1}$ with an average of four scans at $4 \mathrm{~cm}^{-1}$ resolution (Supplementary information Fig. S1).

\section{Size and shape analysis}

The particles were characterised in terms of size, shape and chemical composition. The shape of microplastics as well as the structure of intact mask layers was characterized using a field emission scanning electron microscope (FE-SEM, Zeiss ULTRA plus, Carl Zeiss, Germany). The samples were sputtered before observation with a $10 \mathrm{~nm}$ thin layer of $\mathrm{Au} / \mathrm{Pd}$ coating. Microscopy was performed at $5.3 \mathrm{~mm}$ working distance using a secondary electron detector, $2 \mathrm{kV}$ accelerating voltage and $30 \mu \mathrm{m}$ aperture size. The particle size distribution was determined using a particle sizer Microtrac Bluewave as described in Selonen et al. [35]. The samples were measured in three sequentially performed runs, from which averages were calculated and used in the data analysis. The diameters of the fibres in intact mask layers were evaluated using image $)$ software on SEM images $\left(n_{\text {data }}=60\right.$ for each of the layer).

\section{Gas chromatography-mass spectrometry analysis}

For each of the inner frontal, middle filtering and outer layers of the medical mask, $0.12 \mathrm{~g}$ of the milled material was weighed into glass vials with PTFE lid and $0.7 \mathrm{~g}$ methanol was added. A blank with methanol only was also prepared. The exact mass of the methanol was recorded. The vials were sealed, put in an autoclave and heated to $100^{\circ} \mathrm{C}$ for $144 \mathrm{~h}$. After cooling, the vials were removed and centrifuged at $9000 \mathrm{rpm}$. A small amount of methanol solution was transferred into $0.2-\mathrm{mL}$ GCMS vials using a syringe. A drop of methanol spiked with diethyl adipate as internal standard was added to each, and the vials were sealed. The exact mass of the spiked methanol was also recorded.

Gas chromatography-mass spectrometry analysis was performed on a 7890B gas chromatograph (Agilent, Santa Clara, CA, USA) coupled with a quadrupole mass detector (5977B). The GC-MS conditions were as follows: column, DB-5 MS Ultra Inert (Agilent, Santa Clara, CA, USA); injected volume, $1 \mu \mathrm{L}$; inlet temperature, $250^{\circ} \mathrm{C}$; carrier gas, He; and split ratio, 1:20. Temperature program: Initial 
temperature, $45^{\circ} \mathrm{C}$; hold time, $5 \mathrm{~min}$; ramp rate, $10^{\circ} \mathrm{C} /$ min; final temperature, $300^{\circ} \mathrm{C}$; hold time, $10 \mathrm{~min}$. The components were identified based on the mass spectra in comparison with probability-based matching (Agilent, Santa Clara, CA, USA). A total number of peaks with an initial area $>30,000$ and initial threshold $>15.0$ were counted. Quantitative analysis was performed based on the peak area of each component compared to the peak area of the internal standard. An area of the particular peak from the procedural blank was subtracted. A relative response factor of 1 was used in the calculations.

Toxicity of medical mask microplastics to Daphnia magna Acute toxicity tests were performed according to the ISO 6341:2012 [36]. The daphnids used were derived from Daphtoxkit $\mathrm{F}^{\mathrm{m}}$ magna. Hatched daphnids less than $24 \mathrm{~h}$ old were fed with algae (Desmodesmus subspicatus) for $1.5 \mathrm{~h}$ (density $5 \times 10^{4}$ cells $/ \mathrm{mL}$ ) prior to the microplastics exposure. The microplastics from the milled layers of the medical mask were added to the ISO 6341: 2012 test medium $\left(11.76 \mathrm{~g} \mathrm{CaCl}_{2} 2 \mathrm{H}_{2} \mathrm{O}, 4.93 \mathrm{~g} \mathrm{MgSO}_{4}\right.$ $7 \mathrm{H}_{2} \mathrm{O}, 2.59 \mathrm{~g} \mathrm{NaHCO}_{3}, 0.23 \mathrm{~g} \mathrm{KCl}$, dissolved to $1 \mathrm{~L}$ in water) with $0.0024 \%(\mathrm{v} / \mathrm{v})$ Tween 40 , and the suspensions were stirred with vortex prior to dilutions and pipetting. For each test concentration 4 Petri dish with $10 \mathrm{~mL}$ test medium were prepared, and 5 neonates were placed into each of the Petri dish. Controls that contained only the test medium and test medium with $0.0024 \%(\mathrm{v} / \mathrm{v})$ Tween 40 were included in all of the experiments. The daphnids were exposed for $48 \mathrm{~h}$ at $21 \pm 1{ }^{\circ} \mathrm{C}$ under a 16 : $8 \mathrm{~h} \mathrm{light/dark}$ regime. The exposure during the toxicity testing was static, without mixing of the test suspensions. Three concentrations were tested: $1 \mathrm{mg} \mathrm{L}^{-1}, 10$ $\mathrm{mg} \mathrm{L}^{-1}$ and $100 \mathrm{mg} \mathrm{L}^{-1}$. Two separate experiments were carried out, with 20 daphnids per microplastic and control each time. After $24 \mathrm{~h}$ and $48 \mathrm{~h}$ of exposure, the daphnids were inspected for mobility (according to ISO 6341:2012 [36]), and their mortality was determined by the absence of a heartbeat.

\section{A review of ecotoxicity data on polypropylene microplastics}

The literature search was carried out in September 2021. Two databases: Web of Science and ScienceDirect were searched using two keyword combinations: "microplastics" AND "polypropylene"; and "microplastics" AND "polypropylene" AND "toxic". In both knowledge bases only research articles within Environmental Sciences category were considered. Preliminary title and abstract screening were used to exclude irrelevant literature. In the second stage, the selected papers were inspected in detail for relevance to the review.

\section{Results and discussion}

Characteristics of microplastics obtained from medical masks

Polymer chemistry

The spectra from the Fourier-transform infrared spectroscopy of the inner frontal, middle filtering and outer layers of the mask materials had absorption bands at the same positions and with the same relative intensities as spectra obtained for polypropylene, from the internal database of the Slovenian National Building and Civil Engineering Institute (Supplementary Information Fig. S1). This confirmed that the source mask indeed contained polypropylene.

\section{Size and shape of microplastics}

Two different shapes of microplastics were obtained from the three layers: fibres resulted from milling of the inner and outer layers, while milling of middle layer resulted in irregularly-shaped fragments (FE-SEM Zeiss Ultra Plus; Fig. 1 D-F). This is not surprising given the fact that the composition of the intact source medical mask material was different between the layers: the inner layer and outer layer were very similar in shape being composed of a mesh of fibres with very uniform diameters $(21.2 \pm 1.5 \mu \mathrm{m}$ and $22.1 \pm 1.6 \mu \mathrm{m}$ for inner and outer layer, respectively), while the fibres in the middle layer were significantly thinner $(4.3 \pm 2.2 \mu \mathrm{m})$. The fibres in middle layer had various diameters and the mesh was more compact and interwoven (Fig. $1 \mathrm{~A}-\mathrm{C}$ ). This difference is in line with the fact that these layers are produced using different technological approaches (see introduction and ref. (9)). Also, Ellison et al. [10] reported that thinner fibres are formed by melt-blown process used for the middle layer than by the spun-bond processes used for the inner and outer layers.

We observed that cryo-milling deforms the shape of the original fibres in medical mask. It is unclear how relevant these particles are for ecotoxicity testing in comparison to those released in the environment. Wang et al. [14] reported that different shapes of microplastics, mostly fragments of fibres, were released from the three layers of medical masks after UV weathering. Interestingly, the middle layer was more susceptible to UV than the inner and outer layers. Extraction of fibre fragments from the water after aging could be an option to obtain relevant testing materials, but the recovery in this case is low and would not be sufficient for large scale experiments or for soil toxicity testing where large quantities are needed. Therefore cryo-milling remains the most common approach to produce microplastics for research as it enables sufficient amount of testing material to be produced. Other approaches that had been used previously to produce microplastics from larger plastic items all include some mechanical fragmentation, these are: 

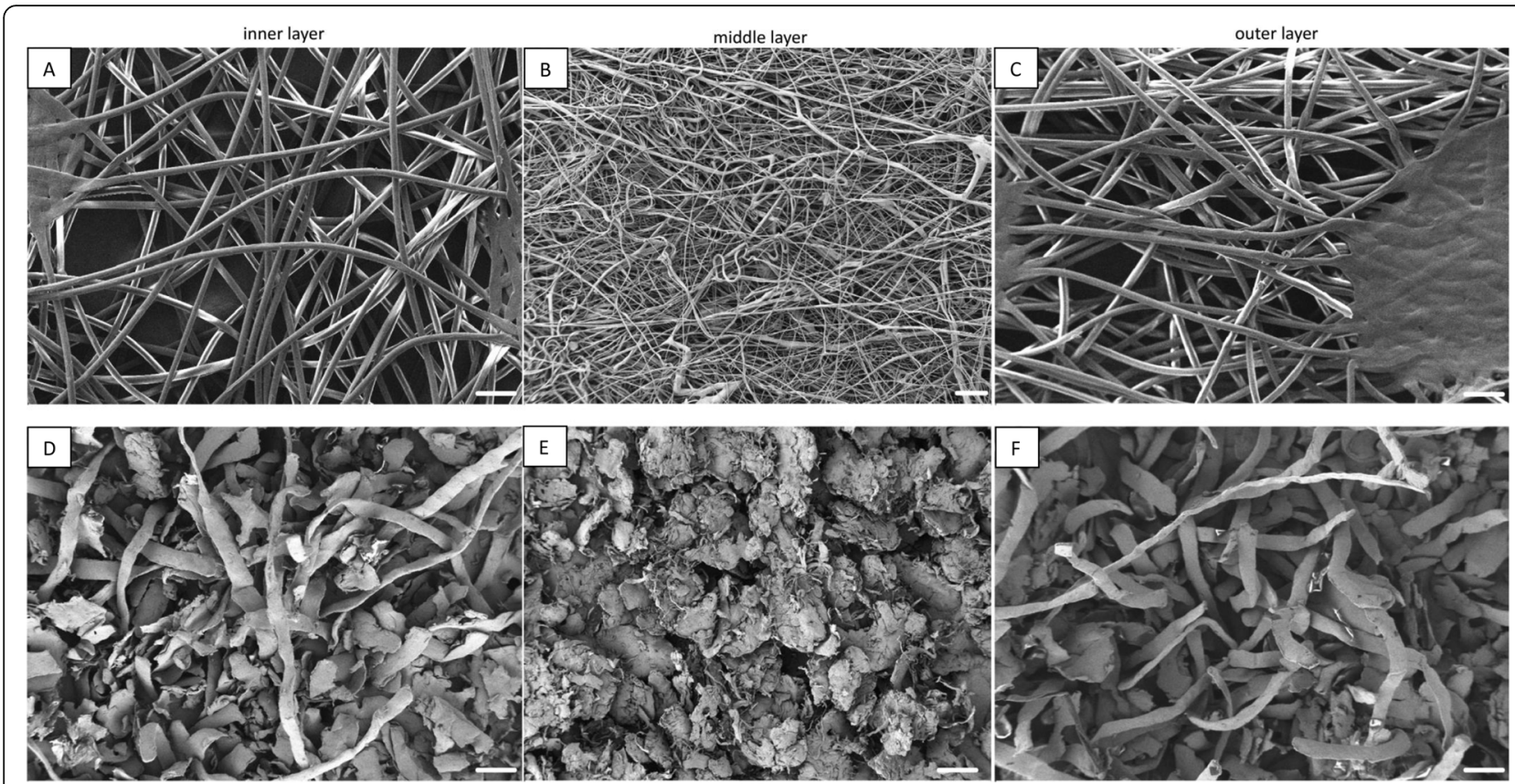

Fig. 1 Representative scanning electron microscopy images of the intact mask layers (A-C) and milled microplastics (D-F) derived from the medical mask inner frontal layer, middle filtering layer and outer layer. White bars on the images represent $100 \mu \mathrm{m}$

cutting with scissors, grinding with mortar and liquid nitrogen, and cutting with cryogenic microtome (Table 1).

The particle size distributions obtained by laser diffraction analysis (Microtrac S3500 Bluewave) were very similar for the inner and outer layers, with mean sizes $( \pm$ standard deviation; expressed as the equivalent diameters of spherical particles) of the fibres of $45.1 \pm 21.5 \mu \mathrm{m}$ and $42.0 \pm 17.8 \mu \mathrm{m}$, respectively. The fragments of the middle filtering layer were slightly larger, at $55.6 \pm$ $28.5 \mu \mathrm{m}$. As can be seen from the size distributions shown in Fig. 2, for the inner, middle and outer layers, 99.1\%, $97.6 \%$ and $99.4 \%$ of the particles, respectively, were $<176 \mu \mathrm{m}$, which is not too surprising given that they were sieved through a $250-\mu \mathrm{m}$ fine-mesh sieve.

Wang et al. [14] reported that the particle size distributions differed between the layers of medical mask weathered in water. The particles from the outer layer were mainly distributed in the range of $20-100 \mu \mathrm{m}$ and 100 $500 \mu \mathrm{m}$, particles from the inner layer were mainly distributed in $30-100 \mu \mathrm{m}$ and $100-500 \mu \mathrm{m}$, and for the middle layer, the particle size of the microplastics was 50$200 \mu \mathrm{m}$. Most of the particles released were less than $200 \mu \mathrm{m}$ in size for all three mask layers, with this trend being particularly pronounced for the middle layer, where this size distribution accounted for $91.2 \%$ of the total concentration. This means that the size range of particles obtained by cryo-milling in our case study is within the environmentally relevant values, although the particle sizes will largely depend on the choice of the parameters used for the milling method as well as for sieving.

\section{Analysis of plastics-associated chemicals}

We analysed extracts from the milled microplastics from the inner frontal, middle filtering and outer layers of the medical mask. GC-MS chromatograms solvent (methanol), procedural blank and of the extracts are presented in Figs. S2-S6 (Supplementary information). The data for the different compounds identified from the three layers of the medical mask are given in Table 1. This revealed several long-chain hydrocarbons; however, many of these are not listed in Table 1 because the identification of long-chain hydrocarbons is not reliable.

Among most common groups of chemicals were: antioxidants, such as 2,4-di-(tert-butyl) phenol; 2,6-di-(tert-butyl)-4(methoxymethyl)phenol and methyl-3,5-bis (1,1-dimethylethyl)-4-hydroxy-benzene-propanoate (also known as Metilox); and lubricants: e.g. methyl palmitate; methyl-3,5-bis (1,1-dimethylethyl)-4-hydroxy-benzene-propanoat; eicosane; methyl stearate and (E)-9-octadecenamide (i.e., oleamide). Some oleamide was detected in the procedural blank as well (Supplementary Fig. S3). Of particular interest, some of the compounds detected from the extraction of the inner layer are commonly used as food flavourings and antimicrobial agents (e.g. 2,4-dimethylanisole; 2,4-dimethylphenol; benzothiazole; heptadecane). The total amounts of the extracted compounds detected by GC-MS were similar for each of the layers of the medical masks (Table 1), but there were indications of many more compounds in the GC-MS chromatogram from the extraction of the inner frontal layer (Supplementary Fig. S2). 
Table 1 Results of the GC-MS analysis for the three layers of the disposable medical mask, with total numbers of peaks detected, combined mass fraction of extracted compounds detected and a list of compounds with $\geq 90 \%$ quality and at levels of $>10 \mu \mathrm{g} / \mathrm{g}$ microplastics. The possible functions of chemicals were extracted from Zimmermann et al. [37] and Groh et al. [38] through the database "Chemicals associated with plastic packaging". For the chemicals which were not listed in any of these two publications, the function was summarised from the PubChem database. Where available, detection in other plastic samples was described (after Zimmermann et al. [37])

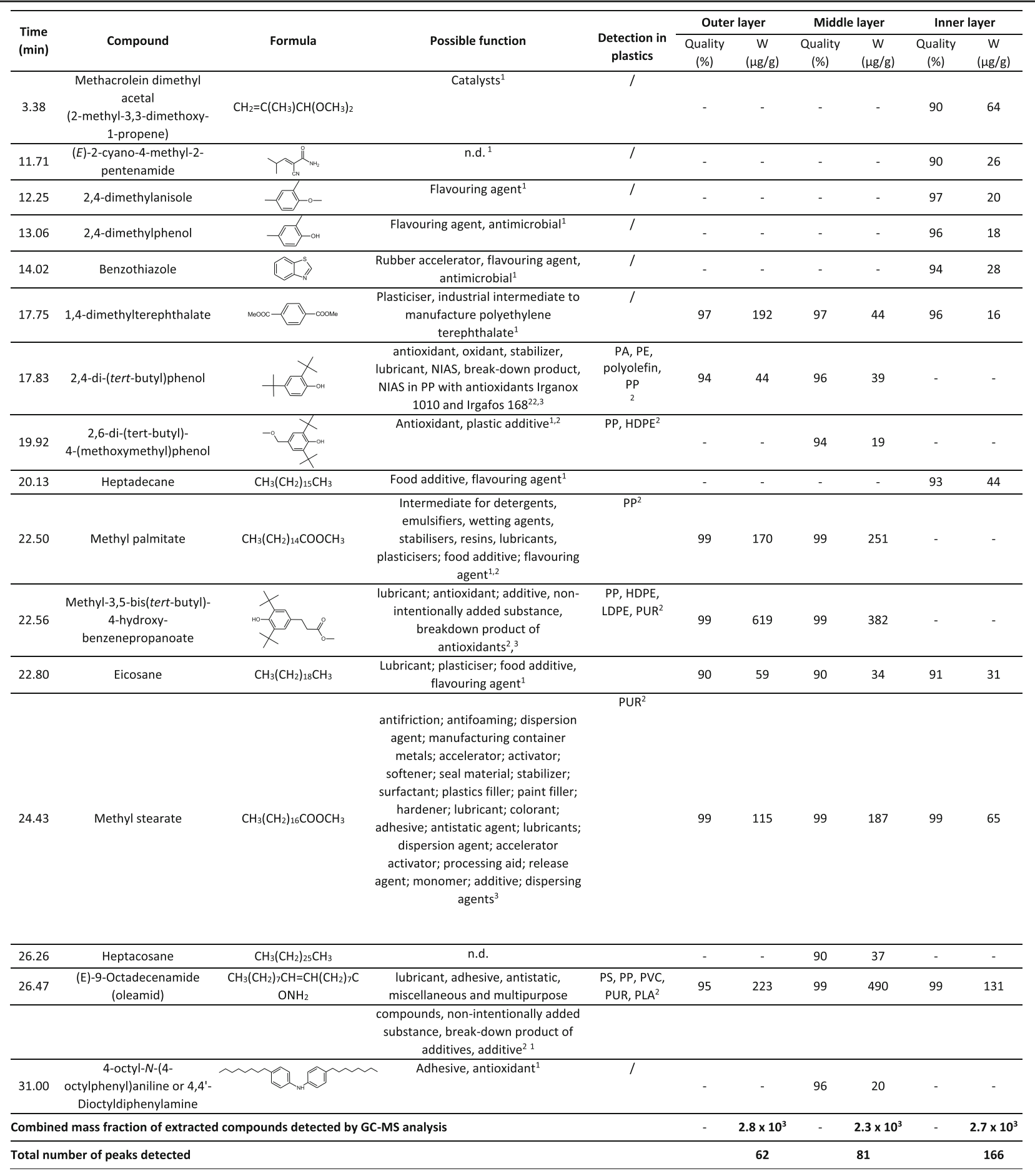

${ }^{1}$ derived from https://pubchem.ncbi.nlm.nih.gov, ${ }^{2}$ Zimmermann et al. [37], ${ }^{3}$ Groh et al. [38]; n.d. could not find the function in plastic production, PPpolypropylene, PVC- polyvinyl chloride, PUR- polyurethane, HDPE- high density polyethylene. 

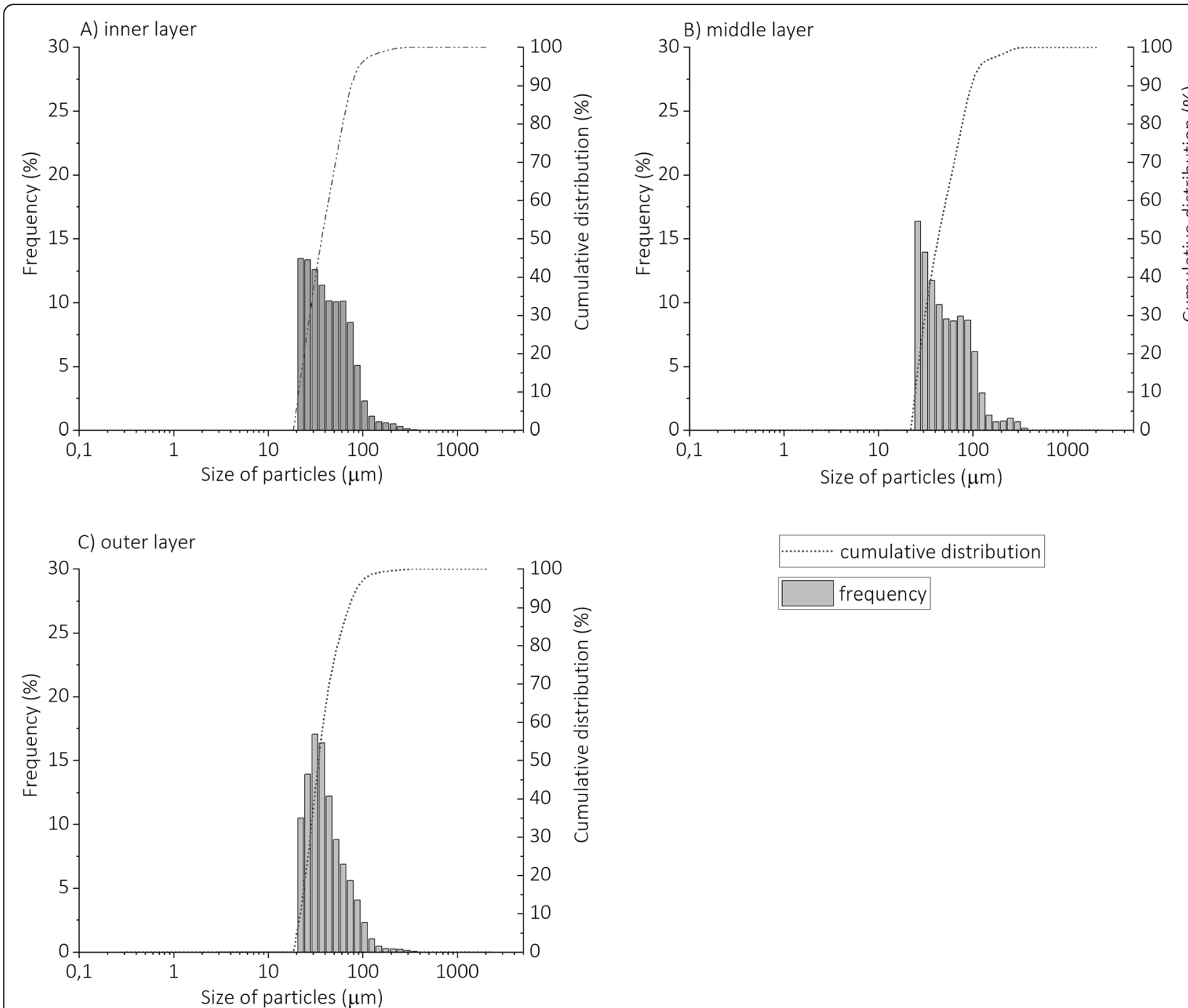

Fig. 2 Numerical particle size distributions of the milled microplastics derived from the medical mask inner frontal layer (A), middle filtering layer (B) and outer layer (C), as determined by laser diffraction analysis

It has been reported that a number of different compounds can leach from polypropylene products [39]. For example, a total of 107 analytes were identified in leachates from polypropylene food containers [39]. Among these, the most abundant groups were antioxidants and their degradation products (tris (2,4-di-tert-buthylphenyl)phosphite; 2,6Di-tert-butyl-4-ethyl-phenol), plasticizers (e.g. bis-(2-ethylhexyl) phthalate; dibutyl phthalate), cross-linking agents (e.g. 2-mercaptobenzothiazole; benzothiazole) and other additives (e.g., antistatic agents; lubricants; non-ionic surfactants) [39]. Similarly, Zimmermann et al. [37] reported a number of chemicals in PP products, for example 18, 5 and 22 different chemicals in gummy candy packaging, handkerchief packaging, and shampoo bottle, respectively. Some of these chemicals were also detected in the medical masks characterised in this study (Table 1). We could not find data specific to medical masks, but there are some records that medical masks might contain formaldehyde and bromo-2nitropropane-1,3-diol (bronopol), which can cause acute dermatitis in healthcare workers [40], but these were not identified in the present samples.

\section{Toxicity of polypropylene microplastics to Daphnia magna}

We observed no effects on the mobility and survival of D. magna exposed to the three types of microplastics that were milled from the three layers of the medical mask at $1 \mathrm{mg} \mathrm{L}^{-1}-100 \mathrm{mg} \mathrm{L}^{-1}$ for $48 \mathrm{~h}$. However, there was attachment of these microplastics to the body surface and ingestion of the microplastics by $D$. magna (Fig. 3). This is in line with our previous work where no acute effects of polyethylene cosmetic beads and polyester textile fibres on D. magna were recorded, but these microplastics were as well found in the gut [41, 42]. 


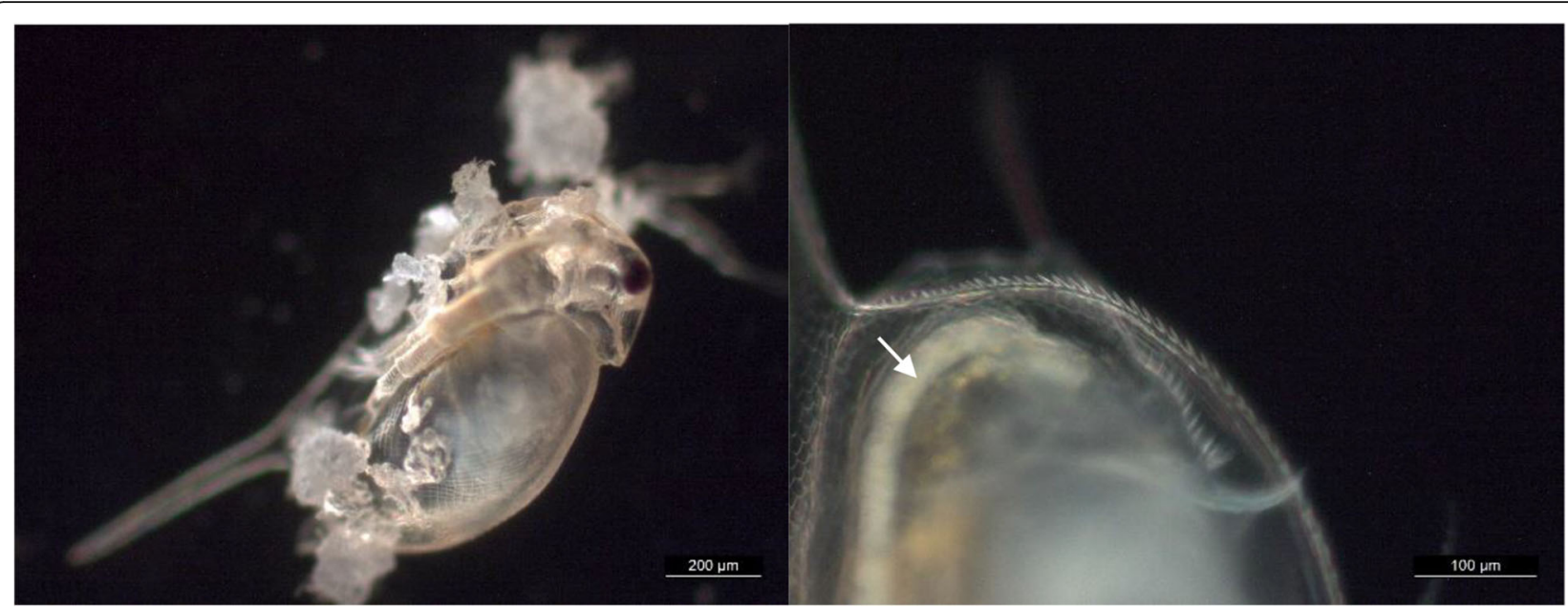

Fig. 3 Representative light microscopy images of Daphnia magna after $48 \mathrm{~h}$ exposure to the medical mask microplastics. Left: Microplastics from the middle filtering layer of the medical mask attached to the body surface of a D. magna. Right: Microplastics from the inner frontal layer of the medical mask in the gut of a D. magna (white arrow)

Acute effects were however observed in the case of polyester textile fibres when the exposure was prolonged for additional $24 \mathrm{~h}$ as the daphnids could not recover from the exposure [41]. We would thus suggest the need for further studies on chronic effects of microplastics from medical masks. Of note, chronic studies have already shown numerous effects of other types of microplastics on D. magna [43, 44]. Furthermore, multigenerational studies with daphnids have shown that some effects, such as decreased reproduction, can persist over at least two generations without further exposure to the microplastics [43]. The choice of exposure scenarios and endpoint selection in future polypropylene microplastics ecotoxicity studies with $D$. magna should also consider the physicochemical properties that appear particular for this type of test material [45], as well as testing for the expected chemically and physically induced interactions of microplastics with the test organisms, for example adsorption onto the body surface and interference with moult.

Although several plastics-associated chemicals were identified in methanol extracts from medical mask microplastics (Table 1), obviously the concentrations in test medium during the acute exposure of $D$. magna were not high enough to cause acute lethal effects. Similarly, when leachates from 26 different plastic products were tested (analysed at $100-250 \mathrm{~g}$ plastics $\mathrm{L}^{-1}$ water), none of the leachates from polypropylene were toxic to the water flea D. magna [46]. Also, in another study, leachates from polypropylene showed the lowest inhibition of the survival and settlement of the barnacle Amphibalanus amphitrite when compared to highdensity and low-density polyethylene, polyvinylchloride, polycarbonate, polyethylene terephthalate, polystyrene (all analysed at $1000-5000 \mathrm{~cm}^{2} \mathrm{~L}^{-1}$ with water; equivalent to $100-500 \mathrm{~g}^{2}$ plastics $\mathrm{L}^{-1}$ water) [47].

Currently, there is only one very recent ecotoxicity study available on the polypropylene microplastics from medical masks [48]. The authors report the effect of microplastics obtained from FFP2 medical mask on springtails Folsomia candida and earthworms Eisenia andrei. The reproduction and growth of juvenile springtails and spermatogenesis of earthworm were decreased already at environmentally relevant concentration (Table 2). No induction of oxidative stress and effects on survival were found for both species. To our knowledge, no data on the effects of medical mask microplastics for aquatic organisms currently exists.

\section{A review of ecotoxicity data on microplastics from other polypropylene-based products}

Many literature reviews have indicated that polypropylene microplastics are among the least studied microplastics in laboratory ecotoxicity studies [77-79]. This is surprising given the fact that polypropylene is the second largest European and global plastic resin in terms of production volume $[80,81]$ and polypropylene microplastics are among the most common found in the environment [77]. For example, of the total of 157 peerreviewed ecotoxicity articles published by 2018 with 612 different microplastics on aquatic organisms, only $12.1 \%$ included polypropylene [33]. Our literature search using the keywords "polypropylene" and "microplastics" (September 2021) resulted in 688 hits within the category Environmental Sciences of the Web of Science knowledge base and 2003 hits within ScienceDirect. For the keyword combination "polypropylene" and 
Table 2 Overview of the ecotoxicity studies on microplastics derived from polypropylene

\begin{tabular}{|c|c|c|c|c|c|c|c|c|}
\hline \multirow[t]{2}{*}{ Species } & \multicolumn{5}{|l|}{ MPs } & \multirow{2}{*}{$\begin{array}{l}\text { Exposure } \\
\text { time }\end{array}$} & \multirow[t]{2}{*}{ Effects } & \multirow[t]{2}{*}{ Ref. } \\
\hline & Form & $\begin{array}{l}\text { Dimension } \\
(\mu \mathrm{m})\end{array}$ & Source material & $\begin{array}{l}\text { Mode of } \\
\text { preparation }\end{array}$ & $\begin{array}{l}\text { Test } \\
\text { concentrations }\end{array}$ & & & \\
\hline $\begin{array}{l}\text { amphipod } \\
\text { Hyalella Azteca } \\
\text { (Crustacea) }\end{array}$ & Fibres & $\begin{array}{l}\text { Diameter: } \\
20 \\
\text { Length: } 20- \\
75\end{array}$ & $\begin{array}{l}\text { Aged marine } \\
\text { fishing rope ( } 3 \\
\text { years under } \\
\text { ambient } \\
\text { conditions) }\end{array}$ & $\begin{array}{l}\text { Cutting the } \\
\text { rope by } \\
\text { scissors }\end{array}$ & $\begin{array}{l}0-90 \text { fibres } \\
\mathrm{mL}^{-1}\end{array}$ & 10 days & $\begin{array}{l}\uparrow \text { Mortality, } \downarrow \text { Growth, } \\
\downarrow \text { Weight; } \uparrow \text { egestion time; } \\
\text { Fibres not retained in the gut } \\
\text { LOEC }=45 \text { fibres } \mathrm{mL}^{-1}\end{array}$ & [49] \\
\hline $\begin{array}{l}\text { shrimp } \\
\text { Palaemonetes } \\
\text { pugio (Crustacea) }\end{array}$ & Fibres & $\begin{array}{l}\text { a) Diameter: } \\
\text { 30-38 } \\
\text { b) Diameter: } \\
\text { 80-105 } \\
\text { Length: not } \\
\text { defined }\end{array}$ & $\begin{array}{l}\text { Aged marine } \\
\text { fishing rope ( } 3 \\
\text { years under } \\
\text { ambient } \\
\text { conditions) }\end{array}$ & $\begin{array}{l}\text { Cutting the } \\
\text { rope by } \\
\text { scissors }\end{array}$ & $\begin{array}{l}50,000 \text { fibres } \\
L^{-1}\end{array}$ & $96 \mathrm{~h}$ & $\begin{array}{l}\text { a) no effect } \\
\text { b) } \uparrow \text { Mortality }\end{array}$ & {$[50]$} \\
\hline $\begin{array}{l}\text { shrimp } \\
\text { Palaemonetes } \\
\text { pugio (Crustacea) }\end{array}$ & $\begin{array}{l}\text { Fragments, } \\
\text { irregular } \\
\text { shapes }\end{array}$ & $\begin{array}{l}30-38 \\
80-105\end{array}$ & $\begin{array}{l}\text { Purchased, TWOH } \\
\text { Chem }\end{array}$ & $\begin{array}{l}\text { Sieving the } \\
\text { powder }\end{array}$ & $\begin{array}{l}50,000 \text { particles } \\
L^{-1}\end{array}$ & $96 \mathrm{~h}$ & No effect & {$[50]$} \\
\hline $\begin{array}{l}\text { shrimp } \\
\text { Litopenaeus } \\
\text { vannamei } \\
\text { (Crustacea) }\end{array}$ & $\begin{array}{l}\text { Fragments, } \\
\text { spherical, } \\
\text { rod- } \\
\text { shaped, } \\
\text { sheet-like }\end{array}$ & $1.77-18$ & $\begin{array}{l}\text { Purchased, China } \\
\text { Petroleum \& } \\
\text { Chemical } \\
\text { Corporation }\end{array}$ & $\begin{array}{l}\text { Used as } \\
\text { received }\end{array}$ & $1 \mathrm{mg} \mathrm{L}^{-1}$ & 14 days & $\begin{array}{l}\text { Changes in gut microbial } \\
\text { composition } \\
\uparrow \text { proteome expression } \\
\text { related to moult processes } \\
\text { and metabolism } \\
\text { Changed metabolic profile } \\
\text { No effect on immune related } \\
\text { proteome expression }\end{array}$ & {$[51]$} \\
\hline $\begin{array}{l}\text { decapod } \\
\text { Nephrops } \\
\text { norvegicus } \\
\text { (Crustacea) }\end{array}$ & Fibres & $\begin{array}{l}\text { Diameter: } \\
200 \text { Length: } \\
\text { 3000-5000 }\end{array}$ & Fishing rope & $\begin{array}{l}\text { Fibres were } \\
\text { removed from } \\
\text { twisted split } \\
\text { rope }\end{array}$ & $\begin{array}{l}\text { Adding } 5 \text { fibres } \\
\text { every two days. } \\
\text { Total fibres at } \\
\text { the end: } 360\end{array}$ & 8 months & $\begin{array}{l}\downarrow \text { Feeding rate; } \\
\downarrow \text { Body mass } \\
\downarrow \text { Metabolic rate } \\
\text { Retention of fibres in foregut }\end{array}$ & {$[52]$} \\
\hline $\begin{array}{l}\text { mole crab } \\
\text { Emerita analoga } \\
\text { (Crustacea) }\end{array}$ & Fibres & $\begin{array}{l}\text { Diameter: } \\
100 \\
\text { Length: } \\
1000\end{array}$ & Fishing rope & $\begin{array}{l}\text { Cutting the } \\
\text { rope by } \\
\text { scissors }\end{array}$ & 3 fibres $L^{-1}$ & 72 days & $\begin{array}{l}\uparrow \text { Mortality } \\
\downarrow \text { Reproductive success }\end{array}$ & [53] \\
\hline $\begin{array}{l}\text { nematode } \\
\text { Caenorhabditis } \\
\text { elegans } \\
\text { (Annelida) }\end{array}$ & $\begin{array}{l}\text { Fragments, } \\
\text { irregular } \\
\text { shapes }\end{array}$ & $<70$ & $\begin{array}{l}\text { Purchased, Sigma- } \\
\text { Aldrich }\end{array}$ & $\begin{array}{l}\text { Ground with } \\
\text { mortar, sieved } \\
<200 \mu \mathrm{m}\end{array}$ & $\begin{array}{l}0.5-5.0 \mathrm{mg} \mathrm{m}^{-2} \\
\text { (agar plate) }\end{array}$ & $48 \mathrm{~h}$ & $\begin{array}{l}\uparrow \text { Mortality; } \downarrow \text { growth; } \downarrow \\
\text { Reproductive success; } \\
\uparrow \text { stress genes } \\
\text { LOEC }=0.5 \mathrm{mg} \mathrm{m}^{-2}\end{array}$ & [54] \\
\hline $\begin{array}{l}\text { nematode } \\
\text { Caenorhabditis } \\
\text { elegans } \\
\text { (Annelida) }\end{array}$ & $\begin{array}{l}\text { Fragments, } \\
\text { irregular } \\
\text { shapes }\end{array}$ & $\begin{array}{l}\text { Three size } \\
\text { ranges: } \\
\text { a) }<250 \\
\text { b) } 250-630 \\
\text { c) } 630-1000\end{array}$ & $\begin{array}{l}\text { Obtained from } \\
\text { Bundesanstalt für } \\
\text { Materialforschung } \\
\text { und prüfung } \\
\text { (Berlin, Germany) }\end{array}$ & $\begin{array}{l}\text { Cryo-milling; } \\
\text { sieving < } \\
1000 \mu \mathrm{m}\end{array}$ & $\begin{array}{l}0.01,0.1 \text { and } \\
1 \% \mathrm{w} / \mathrm{w} \text { soil }\end{array}$ & $24 \mathrm{~h}$ & $\begin{array}{l}\text { a) } \downarrow \text { reproduction at } 1 \% \\
\text { b, c) no effect }\end{array}$ & {$[55]$} \\
\hline $\begin{array}{l}\text { ragworm Hediste } \\
\text { diversicolor } \\
\text { (Annelida) }\end{array}$ & $\begin{array}{l}\text { Fragments, } \\
\text { irregular } \\
\text { shapes }\end{array}$ & $<400$ & $\begin{array}{l}\text { Purchased, supplier } \\
\text { not provided }\end{array}$ & $\begin{array}{l}\text { Cryo-milling; } \\
\text { sieving < } \\
400 \mu \mathrm{m}\end{array}$ & $\begin{array}{l}1 \text { and } 5 \% \mathrm{w} / \mathrm{w} \\
\text { sediment }\end{array}$ & 10 days & $\begin{array}{l}\downarrow \text { coelomocytes viability, } \\
\downarrow \text { phenoloxidase, } \\
\downarrow \text { acid phosphatase, no effect } \\
\text { on phagocytic activity; } \\
\text { LOEC }=10 \mathrm{mg} \mathrm{kg}^{-1}\end{array}$ & {$[56]$} \\
\hline $\begin{array}{l}\text { oyster Crassostrea } \\
\text { gigas (Mollusca) }\end{array}$ & $\begin{array}{l}\text { Fragments, } \\
\text { irregular } \\
\text { shapes }\end{array}$ & $<400$ & $\begin{array}{l}\text { Purchased, supplier } \\
\text { not provided }\end{array}$ & $\begin{array}{l}\text { Cryo-milling; } \\
\text { sieving < } \\
400 \mu \mathrm{m}\end{array}$ & $\begin{array}{l}0.008,10 \\
100 \mu g L^{-1}\end{array}$ & 10 days & $\begin{array}{l}\text { No effects on clearance rate } \\
\text { of organisms, tissue } \\
\text { alteration, antioxidant } \\
\text { defence, immune response } \\
\text { and DNA damage. }\end{array}$ & {$[57]$} \\
\hline $\begin{array}{l}\text { mussel Mytilus } \\
\text { spp (Mollusca) }\end{array}$ & $\begin{array}{l}\text { Fragments, } \\
\text { irregular } \\
\text { shapes }\end{array}$ & $<400$ & $\begin{array}{l}\text { Purchased, supplier } \\
\text { not provided }\end{array}$ & $\begin{array}{l}\text { Cryo-milling; } \\
\text { sieving < } \\
400 \mu \mathrm{m}\end{array}$ & $\begin{array}{l}1 \text { and } 1000 \mathrm{mg} \\
\mathrm{L}^{-1}\end{array}$ & 10 days & $\begin{array}{l}\uparrow \text { antioxidant response } \\
\text { No effect on the clearance } \\
\text { rate, and histopathological } \\
\text { parameters }\end{array}$ & {$[58]$} \\
\hline $\begin{array}{l}\text { mussel Perna } \\
\text { viridis (Mollusca) }\end{array}$ & $\begin{array}{l}\text { Fragments, } \\
\text { irregular } \\
\text { shapes }\end{array}$ & $\begin{array}{l}<30 \\
30-300 \\
300-1000\end{array}$ & $\begin{array}{l}\text { Provided by the } \\
\text { Faculty of } \\
\text { Engineering and } \\
\text { Industrial } \\
\text { Technology, } \\
\text { Silpakorn } \\
\text { University, Thailand }\end{array}$ & $\begin{array}{l}\text { Used as } \\
\text { received }\end{array}$ & $\begin{array}{l}66,333,666, \\
\text { and } 1333 \\
\text { particles } L^{-1}\end{array}$ & $96 \mathrm{~h}$ & $\begin{array}{l}\text { Total mortality after } 96 \mathrm{~h} \text {, } \\
\text { After } 72 \mathrm{~h} 67 \%, 63 \% \text { and } 70 \% \\
\text { mortality for the small, } \\
\text { medium and large particles, } \\
\text { respectively. } \\
\text { About } 90 \% \text { of the available } \\
\text { MPs were rejected as }\end{array}$ & [59] \\
\hline
\end{tabular}


Table 2 Overview of the ecotoxicity studies on microplastics derived from polypropylene (Continued)

\begin{tabular}{llllll}
\hline Species & MPs & & & Exposure \\
\cline { 2 - 4 } & Form & $\begin{array}{l}\text { Dimension } \\
(\mu \mathrm{m})\end{array}$ & Source material & $\begin{array}{l}\text { Mode of } \\
\text { preparation }\end{array}$ & $\begin{array}{l}\text { Test } \\
\text { concentrations }\end{array}$ \\
\hline
\end{tabular}

pseudofaeces by the mussels, with approximately $10 \%$ of

MPs being ingested and accumuled in the soft tissue.

\begin{tabular}{|c|c|c|c|c|c|c|c|c|}
\hline $\begin{array}{l}\text { clam Donax } \\
\text { trunculus } \\
\text { (Mollusca) }\end{array}$ & $\begin{array}{l}\text { Fragments, } \\
\text { irregular } \\
\text { shapes }\end{array}$ & $100-400$ & $\begin{array}{l}\text { Purchased, supplier } \\
\text { not provided, } \\
\text { mixture of pellets } \\
\text { from PP and PE }\end{array}$ & $\begin{array}{l}\text { Cryo-milling; } \\
\text { sieving < } \\
400 \mu \mathrm{m}\end{array}$ & $\begin{array}{l}0.06 \mathrm{~g} \mathrm{~kg}^{-1} \text { of } \\
\text { sand }\end{array}$ & $\begin{array}{l}3 \mathrm{~h}, 1,2,3 \\
4,7,10 \text { and } \\
15 \text { days }\end{array}$ & $\begin{array}{l}\uparrow \text { oxidative stress } \\
\downarrow \text { acetylcholinesterase activity }\end{array}$ & {$[60]$} \\
\hline $\begin{array}{l}\text { barnacle } \\
\text { Amphibalanus } \\
\text { amphitrite } \\
\text { (Crustacea) }\end{array}$ & $\begin{array}{l}\text { a) plastic } \\
\text { square } \\
\text { b) leachate } \\
\text { from } \\
\text { plastic }\end{array}$ & $\begin{array}{l}\text { a) } 4 \mathrm{~cm}^{2} \\
\text { b) } 0.50 \mathrm{~m}^{2} \\
\text { plastic in } 1 \\
\mathrm{~L} \text { seawater }\end{array}$ & $\begin{array}{l}\text { Storage } \\
\text { Container }\end{array}$ & $\begin{array}{l}\text { a) Cutting } \\
\text { b) Soaking for } \\
24 \mathrm{~h}\end{array}$ & $\begin{array}{l}\text { b) } 0.1 \text { and } 0.5 \\
\mathrm{~m}^{2} \mathrm{~L}^{-1}\end{array}$ & $\begin{array}{l}24 \mathrm{~h}, 48 \mathrm{~h}, \\
96 \mathrm{~h}\end{array}$ & $\begin{array}{l}\text { a) } 24 \text { h-96 h: } \uparrow \text { Mortality; } \downarrow \\
\text { Settlement } \\
\text { b) } 24 \text { h: } \uparrow \text { Mortality; } \downarrow \\
\text { Settlement }\end{array}$ & {$[47]$} \\
\hline $\begin{array}{l}\text { microalgae } \\
\text { Spirulina sp }\end{array}$ & Fibres & $\begin{array}{l}\text { Diameter: } \\
15 \\
\text { Length: } \\
1000\end{array}$ & Purchased fibres & Cutting & $\begin{array}{l}300,500,550 \\
\mathrm{mg} \mathrm{L}^{-1}\end{array}$ & 112 days & $\begin{array}{l}\downarrow \text { growth } \\
\text { LOEC }=300 \mathrm{mg} \mathrm{L}^{-1}\end{array}$ & [61] \\
\hline $\begin{array}{l}\text { algae } \\
\text { Chlamydomonas } \\
\text { reinhardtii (Algae) }\end{array}$ & $\begin{array}{l}\text { Fragments, } \\
\text { irregular } \\
\text { shapes }\end{array}$ & $\begin{array}{l}<400- \\
1000\end{array}$ & Disposable cup lid & $\begin{array}{l}\text { Cutting to } 1 \\
\mathrm{~cm}, \mathrm{cryo}^{-} \\
\text {milling; siev- } \\
\text { ing }<400 \mu \mathrm{m}\end{array}$ & $1000 \mathrm{mg} \mathrm{L}^{-1}$ & 72 days & $\begin{array}{l}\text { No effect on growth up to } \\
60 \text { days, } \\
\downarrow \text { growth after } 72 \text { days } \\
\uparrow \text { stress genes, e.g. } \\
\text { polysaccharide biosynthesis } \\
\uparrow \text { formation of } \\
\text { polypropylene-algae hetero- } \\
\text { aggregates }\end{array}$ & {$[62]$} \\
\hline $\begin{array}{l}\text { algae Chlorella } \\
\text { pyrenoidosa; } \\
\text { Microcystis } \\
\text { flosaquae (Algae) }\end{array}$ & $\begin{array}{l}\text { Fragments, } \\
\text { irregular } \\
\text { shapes }\end{array}$ & $\sim 172$ & $\begin{array}{l}\text { Purchased, Aladdin } \\
\text { Industrial } \\
\text { Corporation }\end{array}$ & $\begin{array}{l}\text { Used as } \\
\text { received }\end{array}$ & $\begin{array}{l}5,10,50,100 \\
250,500 \mathrm{mg} \\
\mathrm{L}^{-1}\end{array}$ & 11 days & $\begin{array}{l}\downarrow \text { chlorophyll content } \\
\downarrow \text { photosynthetic activity } \\
\text { LOEC }=5 \mathrm{mg} \mathrm{L}^{-1} \text {, no clear } \\
\text { dose-response }\end{array}$ & {$[63]$} \\
\hline $\begin{array}{l}\text { algae Chlorella } \\
\text { sp. (Algae) }\end{array}$ & $\begin{array}{l}\text { Fragments, } \\
\text { irregular } \\
\text { shapes }\end{array}$ & $\begin{array}{l}100-300 \\
300-500 \\
\text { and } 500- \\
700\end{array}$ & Plastic bag & $\begin{array}{l}\text { Cutting to } \\
\text { smaller } \\
\text { particles, } \\
\text { ground with } \\
\text { cryogenic } \\
\text { mill, sieving }\end{array}$ & $\begin{array}{l}10,250,500 \\
750, \text { and } 1000 \\
\mathrm{mg} \mathrm{L}^{-1}\end{array}$ & 3 days & $\begin{array}{l}\downarrow \text { growth, but very small rate } \\
\text { of inhibition }\end{array}$ & [64] \\
\hline $\begin{array}{l}\text { fish Danio rerio } \\
\text { (embryo) }\end{array}$ & undefined & undefined & $\begin{array}{l}\text { Purchased, Sigma- } \\
\text { Aldrich }\end{array}$ & undefined & $\begin{array}{l}1 \mathrm{mg} \mathrm{L}^{-1} \text { and } \\
10 \mathrm{mg} \mathrm{L}^{-1}\end{array}$ & $96 \mathrm{~h}$ & $\begin{array}{l}\uparrow \text { pericardial sac area } \\
\text { No effect total body size }\end{array}$ & {$[65]$} \\
\hline $\begin{array}{l}\text { fish Danio rerio } \\
\text { (larvae, adults) }\end{array}$ & Fibres & $\begin{array}{l}\text { Diameter } \\
20, \text { length: } \\
50 \pm 26 \text { and } \\
200 \pm 90\end{array}$ & Not reported & $\begin{array}{l}\text { Cutting with } \\
\text { cryogenic } \\
\text { microtome }\end{array}$ & $\begin{array}{l}10 \text { and } 100 \mu g \\
L^{-1}\end{array}$ & $\begin{array}{l}48 \mathrm{~h} \\
\text { larvae, } 21 \\
\text { days } \\
\text { adults }\end{array}$ & $\begin{array}{l}\uparrow \text { intestinal damage, larger } \\
\text { effect for long fibres } \\
\uparrow \text { oxidative stress, } \\
\text { inflammation and lipid } \\
\text { depletion in the larvae gut; } \\
\text { larger effect for long fibres } \\
\downarrow \text { decreased feeding } \\
\text { Changed metabolic profile, } \\
\text { disruption in lipid } \\
\text { metabolism }\end{array}$ & 66] \\
\hline $\begin{array}{l}\text { fish Danio rerio } \\
\text { (adults) }\end{array}$ & $\begin{array}{l}\text { Fragments, } \\
\text { irregular } \\
\text { shapes }\end{array}$ & $<70$ & $\begin{array}{l}\text { Purchased, Sigma- } \\
\text { Aldrich }\end{array}$ & $\begin{array}{l}\text { Ground with } \\
\text { mortar, sieved } \\
<200 \mu \mathrm{m}\end{array}$ & $\begin{array}{l}0.001-10.0 \mathrm{mg} \\
\mathrm{L}^{-1}\end{array}$ & 10 days & $\begin{array}{l}\uparrow \text { Mortality; LOEC }=10 \mathrm{mg} / \mathrm{L} \\
\text { intestinal damage }\end{array}$ & \\
\hline $\begin{array}{l}\text { fish Danio rerio } \\
\text { (adults) }\end{array}$ & $\begin{array}{l}\text { Fragments, } \\
\text { irregular } \\
\text { shapes }\end{array}$ & $1-15$ & $\begin{array}{l}\text { Purchased, } \\
\text { Huachuang plastic } \\
\text { material Co. Ltd. }\end{array}$ & $\begin{array}{l}\text { Ground with } \\
\text { pulverizing } \\
\text { and filtering }\end{array}$ & $0.2 \mathrm{mg} \mathrm{L}^{-1}$ & 28 days & $\begin{array}{l}\uparrow \text { lipid peroxidation in the } \\
\text { gut } \\
\downarrow \text { superoxide dismutase in } \\
\text { liver } \\
\text { Possible oxidative stress }\end{array}$ & {$[67]$} \\
\hline $\begin{array}{l}\text { fish Pimephales } \\
\text { promelas } \\
\text { (embryo) }\end{array}$ & $\begin{array}{l}\text { Fragments, } \\
\text { irregular } \\
\text { shapes }\end{array}$ & 150 to 500 & $\begin{array}{l}\text { Purchased, ASPX } \\
\text { company }\end{array}$ & $\begin{array}{l}\text { Ground using } \\
\text { a burmill } \\
\text { coffee } \\
\text { grinder, } \\
\text { sieved }\end{array}$ & $\begin{array}{l}280 \text { and } 2800 \\
\text { particles/ } \mathrm{L} \text { or } \\
1.43 \mathrm{mg} \mathrm{L}^{-1} \text { and } \\
14.3 \mathrm{mg} \mathrm{L}^{-1}, \\
\text { respectively. }\end{array}$ & 14 days & $\begin{array}{l}\uparrow \text { body weight } \\
\text { No effect on hatching } \\
\text { success, survival, and length }\end{array}$ & 00] \\
\hline
\end{tabular}


Table 2 Overview of the ecotoxicity studies on microplastics derived from polypropylene (Continued)

\begin{tabular}{|c|c|c|c|c|c|c|c|c|}
\hline \multirow[t]{2}{*}{ Species } & \multicolumn{5}{|l|}{ MPs } & \multirow{2}{*}{$\begin{array}{l}\text { Exposure } \\
\text { time }\end{array}$} & \multirow[t]{2}{*}{ Effects } & \multirow[t]{2}{*}{ Ref. } \\
\hline & Form & $\begin{array}{l}\text { Dimension } \\
(\mu \mathrm{m})\end{array}$ & Source material & $\begin{array}{l}\text { Mode of } \\
\text { preparation }\end{array}$ & $\begin{array}{l}\text { Test } \\
\text { concentrations }\end{array}$ & & & \\
\hline & & & & $\begin{array}{l}150 \mu \mathrm{m}< \\
500 \mu \mathrm{m}\end{array}$ & & & & \\
\hline $\begin{array}{l}\text { fish Dicentrarchus } \\
\text { labrax (adults) }\end{array}$ & $\begin{array}{l}\text { Fragments, } \\
\text { irregular } \\
\text { shapes }\end{array}$ & $700-1000$ & $\begin{array}{l}\text { Purchased, Sigma- } \\
\text { Aldrich }\end{array}$ & $\begin{array}{l}\text { Ground with } \\
\text { a cutting mill, } \\
\text { sieving to } \\
\text { obtain the } \\
700-1000 \mu \mathrm{m} \\
\text { fraction }\end{array}$ & $10 \% \mathrm{w} / \mathrm{w}$ & 60 days & $\begin{array}{l}\text { No effect on growth } \\
\text { No effect on gut histology } \\
\uparrow \text { immune-related genes }\end{array}$ & [69] \\
\hline $\begin{array}{l}\text { earthworm } \\
\text { Metaphire } \\
\text { guillelmi } \\
\text { (Annelida) }\end{array}$ & $\begin{array}{l}\text { Fragments, } \\
\text { irregular } \\
\text { shapes }\end{array}$ & 13 & $\begin{array}{l}\text { Purchased, } \\
\text { Huachuang } \\
\text { Plasticizing } \\
\text { Corporation }\end{array}$ & $\begin{array}{l}\text { Used as } \\
\text { received }\end{array}$ & $0.25 \% \mathrm{w} / \mathrm{w}$ soil & 28 days & $\begin{array}{l}\text { No changes in gut } \\
\text { microbiota }\end{array}$ & [70] \\
\hline $\begin{array}{l}\text { earthworms } \\
\text { Eisenia fetida } \\
\text { (Annelida) }\end{array}$ & $\begin{array}{l}\text { Fragments, } \\
\text { irregular } \\
\text { shapes }\end{array}$ & $\begin{array}{l}8-125,71- \\
383 \text { and } \\
761-1660\end{array}$ & $\begin{array}{l}\text { Purchased, } \\
\text { Huachuang } \\
\text { Plasticizing } \\
\text { Corporation }\end{array}$ & $\begin{array}{l}\text { Grinding with } \\
\text { liquid } \\
\text { nitrogen }\end{array}$ & $0.25 \%$ w/w soil & $\begin{array}{l}14 \text { days, } \\
28 \text { days }\end{array}$ & $\begin{array}{l}\downarrow \text { antioxidant enzymes } \\
\text { activities }(14 \mathrm{~d}, 28 \mathrm{~d}) \\
\uparrow \text { DNA damage }(28 \mathrm{~d}) \\
\text { No changes in lipid } \\
\text { peroxidation ( } 28 \mathrm{~d})\end{array}$ & [71] \\
\hline $\begin{array}{l}\text { earthworms } \\
\text { Eisenia fetida } \\
\text { (Annelida) }\end{array}$ & $\begin{array}{l}\text { Fragments, } \\
\text { irregular } \\
\text { shapes }\end{array}$ & $<150$ & $\begin{array}{l}\text { Purchased, Sigma- } \\
\text { Aldrich }\end{array}$ & $\begin{array}{l}\text { Mechanically } \\
\text { ground, } \\
\text { sieving }< \\
150 \mu \mathrm{m}\end{array}$ & $\begin{array}{l}0.03,0.3,0.6 \\
0.9 \% \mathrm{w} / \mathrm{w}\end{array}$ & $\begin{array}{l}14 \text { days, } \\
28 \text { days, } \\
42 \text { days }\end{array}$ & $\begin{array}{l}\downarrow \text { growth }(14,21 \text { and } 42 \\
\text { days); LOEC }=0.6 \% \\
\uparrow \text { mortality ( } 42 \text { days), LOEC = } \\
0.3 \% \\
\uparrow \text { lipid peroxidation }(14,21 \\
\text { and } 42 \text { days); } \mathrm{LOEC}=0.03 \% ; \\
\uparrow \text { antioxidant levels }(14,21 \\
\text { and } 42 \text { days); } \mathrm{LOEC}=0.3 \%\end{array}$ & [72] \\
\hline $\begin{array}{l}\text { White worm } \\
\text { Enchytraeus } \\
\text { crypticus } \\
\text { (Annelida) }\end{array}$ & $\begin{array}{l}\text { Fragments, } \\
\text { irregular } \\
\text { shapes }\end{array}$ & $\begin{array}{l}49 \\
141 \\
1520\end{array}$ & Not reported & $\begin{array}{l}\text { Cryo-milling, } \\
\text { sanding, } \\
\text { sieving }\end{array}$ & $\begin{array}{l}0.032,0.1,0.32 \\
0.64 \% \mathrm{w} / \mathrm{w}\end{array}$ & 64 days & No effect on reproduction & [73] \\
\hline $\begin{array}{l}\text { springtails } \\
\text { Folsomia candida } \\
\text { (Entognatha) } \\
\text { earthworms } \\
\text { Eisenia Andrei } \\
\text { (Annelida) }\end{array}$ & $\begin{array}{l}\text { Fibres and } \\
\text { fragments }\end{array}$ & $<300$ & $\begin{array}{l}\text { Triple-layered } \\
\text { disposable white } \\
\text { face masks }\end{array}$ & $\begin{array}{l}\text { cut using } \\
\text { micro-scissors, } \\
\text { and sieved }< \\
300 \mu \mathrm{m}\end{array}$ & $0.1 \% \mathrm{w} / \mathrm{w}$ & 28 days & $\begin{array}{l}\downarrow \text { reproduction and growth } \\
\text { of juveniles springtails } \\
\text { No effect on survival, } \\
\text { esterase activity, oxidative } \\
\text { stress, and light avoidance } \\
\text { behavior of adult springtails } \\
\downarrow \text { esterase activity and } \\
\text { spermatogenesis of } \\
\text { earthworms } \\
\text { No effect on survival and } \\
\text { oxidative stress in } \\
\text { earthworms }\end{array}$ & [48] \\
\hline $\begin{array}{l}\text { Mealworm larvae } \\
\text { Tenebrio molitor } \\
\text { (Insecta) }\end{array}$ & Fragments & $2000-3000$ & $\begin{array}{l}\text { Purchased, } \\
\text { SINOPEC (China) } \\
\text { and Eyelslet } \\
\text { (China) }\end{array}$ & $\begin{array}{l}\text { cut into } 2-3 \\
\mathrm{~mm} \\
\text { fragments }\end{array}$ & $\begin{array}{l}100 \% \text { (fed on } \\
\text { this material) } \\
\text { And } 50 \% \text { mixed } \\
\text { with bran }\end{array}$ & 14 days & $\begin{array}{l}\text { Decomposition and feeding } \\
\text { occur only in case of 50\% } \\
\text { No effect on survival }\end{array}$ & [74] \\
\hline $\begin{array}{l}\text { garden cress } \\
\text { Lepidium sativum }\end{array}$ & $\begin{array}{l}\text { Fibres and } \\
\text { fragments }\end{array}$ & $<125$ & Not reported & $\begin{array}{l}\text { grinding, with } \\
\text { liquid } \\
\text { nitrogen, } \\
\text { sieving }< \\
125 \mu \mathrm{m}\end{array}$ & $0.02 \%(w / w)$ & $\begin{array}{l}6 \text { days, } 21 \\
\text { days }\end{array}$ & $\begin{array}{l}\downarrow \text { biomass, No effect on } \\
\text { reactive oxygen species } \\
\text { formation and antioxidants } \\
\text { content, change ration } \\
\text { between pigments }\end{array}$ & [75] \\
\hline $\begin{array}{l}\text { plant Cucurbita } \\
\text { pepo }\end{array}$ & $\begin{array}{l}\text { Fibres and } \\
\text { fragments }\end{array}$ & $40-50$ & $\begin{array}{l}\text { Purchased, Sigma- } \\
\text { Aldrich }\end{array}$ & Not reported & $\begin{array}{l}0.02,0.1,0.2 \% \\
w / w\end{array}$ & 28 days & $\begin{array}{l}\downarrow \text { root and shoot growth } \\
\text { No effect on leaf area and } \\
\text { photosynthesis } \\
\text { Changes in concentrations of } \\
\text { elements in leaves }\end{array}$ & [76] \\
\hline
\end{tabular}


"microplastics" and "toxic" the number of hits was 59 and 1175 for Web of Science (WoS) and ScienceDirect, respectively (Table S1 Supplementary information). After abstract inspection, in total 27 studies were identified as ecotoxicity studies including species being relevant for this review. An additional 3 were found in the review by De Sá et al. [33] dealing with microplastics from fishing ropes which were not identified during our search in WoS or ScienceDirect. Interestingly, $44 \%$ of studies included in our review were recently published (2021) which indicates that the number of studies on polypropylene microplastics has increased significantly (Supplementary information Table S1, Table 2).

Three types of polypropylene microplastics have been studied in terms of their shapes and sources: fibres from the cutting of fishing rope; fragments obtained from cryo-milling of different products; and purchased fragments (pellets) from polymer producing companies. A comparative analysis of the reported adverse effects across the test species for exposure concentrations and with other microplastic polymer types is very difficult, because the various studies have used a range of test materials of different dimensions (fibres: length 20$1000 \mu \mathrm{m}$, width $15-200 \mu \mathrm{m}$; fragments: diameter $\sim 10$ $3000 \mu \mathrm{m})$, and according to different concentration metrics (particle mass/volume, particle number/volume, particle mass/mass sediment or soil, particle mass/surface area of agar plate) and toxicity endpoints. Also, it was not possible to find a difference between the effects of polypropylene fibres and fragments, although it was suggested previously that the shape of the microplastics has a predominant role in some adverse effects, with fibres showing greater toxicity $[49,50]$.

Nevertheless, it can be concluded that both polypropylene fibres and fragments have the potential to induce adverse effects on organisms at concentrations that can already be found in the environment $[49,52,53,55]$, although some studies also tested unrealistically high microplastics levels [50] (Table 2). The environmental relevance of some of the test concentrations is difficult to assess, as the measurement metrics are different from those most commonly reported in monitoring studies (i.e., particles volume $\mathrm{e}^{-1}$ or $\mathrm{km}^{-2}$ ) [82]. The potentially adverse effects induced by polypropylene microplastics are similar to those induced by other types of microplastics [33], and include: their retention in the gut; decreased feeding and growth rates; changed metabolic rates and metabolic processes; changes in moult process; decreased reproduction; stress induction, oxidative stress and antioxidant responses; induction of immune responses; alteration of the gut microbiome; and (very rarely) mortality (Table 2). However, as Rochman et al. [83] emphasised, microplastics represent a diverse suite of contaminants that show a range of different molecular structures, monomer compositions, chemical additives, sizes, shapes and colours, with many of these potentially involved in their toxicity potential. It is therefore imprecise to generalise toxicity data across microplastics types, even within the same polymer group. This implies the need for new experimental data for polypropylene microplastics from medical masks as currently only such study exists [48]. In particular, such studies should be directed towards the investigation of microplastics from weathered medical masks. Weathering affects not only the surface properties of the particles, but also the release of the additives and the plastic-derived intermediates, as well as the sorption of other environmental pollutants $[18,84,85]$. This can lead to alterations to the behaviour of the microplastics and to their bioavailability to organisms (i.e., the form in which they are available for organisms to ingest), and ultimately to their hazard potential $[18,86,87]$.

\section{Conclusions and outlook}

We have presented a case study of mechanically induced formation of polypropylene microplastics from a commercially available medical mask. Different types of microplastics were obtained from the three layers of the mask, as fibres from the inner frontal and outer layers, and irregularly shaped fragments from the middle filtering layer. The shape of the obtained microplastics differed from the initial fibrous structure of the intact medical mask layers, which indicates that the material is deformed during cryo-milling. Microplastics from the three layers differed in the organic chemical composition of their leachates. The inner frontal layer that comes into contact with the face contained more additives that function as antimicrobials and flavourings, while the middle filtering and outer layers contained more antioxidants, plasticisers and lubricants. Our preliminary acute toxicity study using the standard test organism D. magna did not show any severe effects of these microplastics at relatively high exposure concentrations, although adsorption and ingestion of the particles by the daphnids was observed. As evident from the review on the ecotoxicity of polypropylene microplastics derived from other polypropylene products these can induce various adverse effects on organisms at environmentally relevant values. Due to the increasing use of medical protective masks we thus suggest the need for a thorough investigation into the environmental hazards and impacts of medical mask microplastics on the environment. Further chronic ecotoxicity studies and multigeneration studies with a suite of ecotoxicity test organisms are needed. 
With the development and widespread use of new advanced materials for air filtration [9] also other types of microplastics and nanoplastics could be released into the environment from medical masks. The most popular advanced materials are polymer nanofibre membranes, electret membranes, and porous filters based on metalorganic frameworks [88-90]. Filtration materials can also be treated or coated with numerous antimicrobial agents, such as metal nanoparticles, organic compounds, organic acids and sodium chloride [9]. Silver nanoparticles are often added to such materials, which can release silver ions into the environment, which pose an additional hazard [91]. There are many other variations of filtering materials under investigation, and each of these might also release different types of microplastics and/or nanoplastics.

At this point, it remains unknown how great the environmental burden of improper disposal of medical masks is. However, it is certain that the production volume and use of disposable medical masks will continue to expand globally.

\section{Supplementary Information}

The online version contains supplementary material available at https://doi. org/10.1186/s43591-021-00020-0.

\section{Additional file 1}

\section{Acknowledgements}

The part of the analysis the was performed using GC-MS was within the scope of contract C3330-18-952000 and Consortium Agreement 2017/1, granted by the Ministry of Education, Science and Sport of Republic of Slovenia, with the investment co-financed by the Republic of Slovenia, Ministry of Education, Science and Sport and the European Regional Development Fund. We thank Christopher Berrie for English language revision.

\section{Authors' contributions}

A.J.K.- Conceptualization; Data curation; Funding acquisition; Roles/Writing original draft; Writing - review \& editing; A.D.- Methodology; Writing - review \& editing; D.D.- Funding acquisition; Writing - review \& editing; M.MMethodology; M.D.- Methodology; L.Š- Methodology; Data curation; Formal analysis; G.S- Methodology; B.M.- Writing - review \& editing; A.S.Š- Funding acquisition; Writing - review \& editing. The author(s) read and approved the final manuscript.

\section{Funding}

This research was funded by the Slovenian Research Agency (ARRS) through the research programmes 'Integrative zoology and speleobiology' (grant number P1-0184), 'Geoenvironment and geomaterials' (grant number P10195), 'Building structures and materials' (P2-0273), and through research project J1-2482. Andraž Dolar receives ARRS funding for postgraduate research.

\section{Availability of data and materials}

Not applicable.

\section{Declarations}

Competing interests

Authors declare no competing interests

\section{Author details}

'Department of Biology, Biotechnical Faculty, University of Ljubljana, Večna pot 111, SI-1000 Ljubljana, Slovenia. ${ }^{2}$ Faculty of Chemistry and Chemical Technology, Chair of Materials and Polymer Science, University of Ljubljana, Večna pot 113, SI-1000 Ljubljana, Slovenia. ${ }^{3}$ Department of Geology, Faculty of Natural Sciences and Engineering, University of Ljubljana, Aškerčeva 12, SI-1000 Ljubljana, Slovenia. ${ }^{4}$ Slovenian National Building and Civil

Engineering Institute, Dimičeva ulica 12, SI-1000 Ljubljana, Slovenia.

Received: 2 July 2021 Accepted: 1 December 2021

Published online: 04 January 2022

\section{References}

1. European Centre for Disease Prevention and Control (ECDC). https://www. ecdc.europa.eu/sites/default/files/documents/COVID-19-use-medical-maskscommunity.pdf. Accessed 1 July 2021.

2. Prata JC, Silva ALP, Walker TR, Duarte AC, Rocha-Santos T. COVID-19 pandemic repercussions on the use and management of plastics. Environ Sci Technol. 2020;54(13):7760-5. https://doi.org/10.1021/acs.est.0c02178.

3. Prather KA, Wang CC, Schooley RT. Reducing transmission of SARS-CoV-2: masks and testing are necessary to combat asymptomatic spread in aerosols and droplets. Science. 2020;368(6498):1422-4. https://doi.org/10.112 6/science.abc6197.

4. Worby $\mathrm{CJ}$, Chang $\mathrm{HH}$. Face mask use in the general population and optimal resource allocation during the COVID-19 pandemic. Nat Commun. 2020; 11(1):4049. https://doi.org/10.1038/s41467-020-17922-x.

5. Statista. https://www.statista.com/statistics/1099824/china-medical-mask-a nnual-production-volume/. Accessed 1 july 2021.

6. Aragaw TA. Surgical face masks as a potential source for microplastic pollution in the COVID-19 scenario. Mar Pollut Bull. 2020;159:111517. https:// doi.org/10.1016/j.marpolbul.2020.111517.

7. Fadare OO, Okoffo ED. Covid-19 face masks: a potential source of microplastic fibres in the environment. Sci Total Environ. 2020;737:140279. https://doi.org/10.1016/j.scitotenv.2020.140279.

8. O'dowd K, Nair KM, Forouzandeh P, Mathew S, Grant J, Moran R, et al. Face masks and respirators in the fight against the COVID-19 pandemic: a review of current materials, advances and future perspectives. Materials. 2020; 13(15):3363. https://doi.org/10.3390/ma13153363.

9. Chua MH, Cheng W, Goh SS, Kong J, Li B, Lim JYC, et al. Face masks in the new COVID-19 normal: materials, testing, and perspectives. Research. 2020; 2020:7286735-40. https://doi.org/10.34133/2020/7286735.

10. Ellison CJ, Phatak A, Giles DW, Macosko CW, Bates FS. Melt blown nanofibres: fibre diameter distributions and onset of fibre breakup. Polymer. 2007;48(11):3306-16. https://doi.org/10.1016/j.polymer.2007.04.005.

11. Jung $S$, Lee S, Dou X, Kwon EE. Valorization of disposable COVID-19 mask through the thermo-chemical process. Chem Eng J. 2021;405:126658. https://doi.org/10.1016/j.cej.2020.126658.

12. Sigler $M$. The effects of plastic pollution on aquatic wildlife: current situations and future solutions. Water Air Soil Pollut. 2014;225(11):1-9. https://doi.org/10.1007/s11270-014-2184-6.

13. Chen X, Chen X, Liu Q, Zhao Q, Xiong X, Wu C. Used disposable face masks are significant sources of microplastics to environment. Environ Pollut. 2021; 285:117485. https://doi.org/10.1016/j.envpol.2021.117485.

14. Wang Z, An C, Chen X, Lee K, Zhang B, Feng Q. Disposable masks release microplastics to the aqueous environment with exacerbation by natural weathering. J Hazard Mater. 2021;417:126036. https://doi.org/10.1016/j.jha zmat.2021.126036.

15. Arp HPH, Kühnel D, Rummel C, MacLeod M, Potthoff A, Reichelt $\mathrm{S}$, et al. Weathering plastics as a planetary boundary threat: exposure, fate, and hazards. Environ Sci Technol. 2021;55(11):7246-55. https://doi.org/10.1021/a cs.est.1c01512

16. Enfrin M, Dumée LF, Lee J. Nano/microplastics in water and wastewater treatment processes - origin, impact and potential solutions. Water Res. 2019;161:621-38. https://doi.org/10.1016/j.watres.2019.06.049.

17. Jahnke A, Arp HPH, Escher BI, Gewert B, Gorokhova E, Kühnel D, et al. Reducing uncertainty and confronting ignorance about the possible impacts of weathering plastic in the marine environment. Environ Sci Technol Lett. 2017;4(3):85-90. https://doi.org/10.1021/acs.estlett.7b00008.

18. Liu P, Zhan X, Wu X, Li J, Wang H, Gao S. Effect of weathering on environmental behavior of microplastics: properties, sorption and potential 
risks. Chemosphere. 2020;242:125193. https://doi.org/10.1016/j. chemosphere.2019.125193.

19. Song YK, Hong SH, Jang M, Han GM, Jung SW, Shim WJ. Combined effects of uv exposure duration and mechanical abrasion on microplastic fragmentation by polymer type. Environ Sci Technol. 2017;51(8):4368-76. https://doi.org/10.1021/acs.est.6b06155.

20. Gewert B, Plassmann MM, Macleod M. Pathways for degradation of plastic polymers floating in the marine environment. Environ Sci Process Impacts. 2015;17(9):1513-21. https://doi.org/10.1039/C5EM00207A.

21. De MM, Forte C, Montagna LS, Madalena M, Marlene R, Santana C. Induced degradation of polypropylene with an organic pro-degradant additive polyolefins properties and applications view project polymer blends view project induced degradation of polypropylene with an organic prodegradant additive greek letters. Mater Sci Eng A. 2013;3:123.

22. Rajakumar K, Sarasvathy V, Thamarai Chelvan A, Chitra R, Vijayakumar CT. Natural weathering studies of polypropylene. J Polym Environ. 2009;17(3): 191-202. https://doi.org/10.1007/s10924-009-0138-7.

23. Tocháček J, Vrátníčková Z. Polymer life-time prediction: the role of temperature in UV accelerated ageing of polypropylene and its copolymers. Polym Test. 2014;36:82-7. https://doi.org/10.1016/j.polymertesting.2014.03.019.

24. Bajer K, Braun U. Different aspects of the accelerated oxidation of polypropylene at increased pressure in an autoclave with regard to temperature, pretreatment and exposure media. Polym Test. 2014;37:10211. https://doi.org/10.1016/j.polymertesting.2014.05.006

25. Esmizadeh E, Tzoganakis C, Mekonnen TH. Degradation behavior of polypropylene during reprocessing and its biocomposites: thermal and oxidative degradation kinetics. Polymers. 2020;12(8):1627. https://doi.org/1 0.3390/polym12081627.

26. Lv Y, Huang Y, Kong M, Yang Q, Li G. Multivariate correlation analysis of outdoor weathering behavior of polypropylene under diverse climate scenarios. Polym Test. 2017;64:65-76. https://doi.org/10.1016/j. polymertesting.2017.09.040

27. Hahladakis JN, Velis CA, Weber R, lacovidou E, Purnell P. An overview of chemical additives present in plastics: migration, release, fate and environmental impact during their use, disposal and recycling. Hazard Mater. 2018;344:179-99. https://doi.org/10.1016/j.jhazmat.2017.10.014.

28. Acharya S, Rumi SS, Hu Y, Abidi N. Microfibres from synthetic textiles as a major source of microplastics in the environment: a review. Text Res J. 2021; 91(17-18):2136-56. https://doi.org/10.1177/0040517521991244.

29. De Falco F, Cocca M, Avella M, Thompson RC. Microfibre release to water, via laundering, and to air, via everyday use: a comparison between polyester clothing with differing textile parameters. Environ Sci Technol. 2020;54(6):3288-96. https://doi.org/10.1021/acs.est.9b06892.

30. Rochman CM. Microplastics research - from sink to source in freshwater systems. Science. 2018;360(6384):28-9. https://doi.org/10.1126/science.aa r7734.

31. Yu Q, Hu X, Yang B, Zhang G, Wang J, Ling W. Distribution, abundance and risks of microplastics in the environment. Chemosphere. 2020;249:126059. https://doi.org/10.1016/j.chemosphere.2020.126059.

32. Ma H, Pu S, Liu S, Bai Y, Mandal S, Xing B. Microplastics in aquatic environments: toxicity to trigger ecological consequences. Environ Pollut. 2020;261:114089. https://doi.org/10.1016/j.envpol.2020.114089.

33. De Sá LC, Oliveira M, Ribeiro F, Rocha TL, Futter MN. Studies of the effects of microplastics on aquatic organisms: what do we know and where should we focus our efforts in the future? Sci Total Environ. 2018;645:1029-39. https://doi.org/10.1016/j.scitotenv.2018.07.207.

34. De Ruijter VN, Redondo-Hasselerharm PE, Gouin T, Koelmans AA. Quality criteria for microplastic effect studies in the context of risk assessment: a critical review. Environ Sci Technol. 2020;54(19):11692-705. https://doi.org/1 0.1021/acs.est.0c03057.

35. Selonen S, Dolar A, Jemec Kokalj A, Skalar T, Parramon Dolcet L, Hurley R, et al. Exploring the impacts of plastics in soil - the effects of polyester textile fibres on soil invertebrates. Sci Total Environ. 2020;700:134451. https://doi.org/10.1016/j.scitotenv.2019.134451.

36. EN ISO 6341, 2012. Water quality - determination of the inhibition of the mobility of Daphnia magna Straus (Cladocera, Crustacea) — acute toxicity test. International Organization for Standardization, Geneve.

37. Zimmermann L, Dierkes G, Ternes TA, Vö C, Wagner M. Benchmarking the in vitro toxicity and chemical composition of plastic consumer products. Environ Sci Technol. 2019;53(19):11467-77. https://doi.org/10.1021/acs.est. 9b02293.
38. Groh KJ, Backhaus T, Carney-Almroth B, Geueke B, Inostroza PA, Lennquist A, et al. Overview of known plastic packaging-associated chemicals and their hazards. Sci Total Environ. 2019;651:3253-68. https://doi.org/10.1016/j. scitotenv.2018.10.015.

39. Carrero-Carralero C, Escobar-Arnanz J, Ros M, Jiménez-Falcao S, Sanz ML, Ramos L. An untargeted evaluation of the volatile and semi-volatile compounds migrating into food simulants from polypropylene food containers by comprehensive two-dimensional gas chromatography-timeof-flight mass spectrometry. Talanta. 2019;195:800-6. https://doi.org/10.101 6/j.talanta.2018.12.011.

40. Aerts O, Dendooven E, Foubert K, Stappers S, Ulicki M, Lambert J. Surgical mask dermatitis caused by formaldehyde (releasers) during the COVID-19 pandemic. Contact Dermatitis. 2020;83(2):172-3. https://doi.org/10.1111/ cod. 13626.

41. Jemec A, Horvat P, Kunej U, Bele M, Kržan A. Uptake and effects of microplastic textile fibres on freshwater crustacean Daphnia magna. Environ Pollut. 2016;219:201-9. https://doi.org/10.1016/j.envpol.2016.10.037.

42. Jemec Kokalj A, Horvat P, Skalar T, Kržan A. Plastic bag and facial cleanser derived microplastic do not affect feeding behaviour and energy reserves of terrestrial isopods. Sci Total Environ. 2018;615:761-6. https://doi.org/10.1016/ j.scitotenv.2017.10.020

43. Xu EG, Cheong RS, Liu L, Hernandez LM, Azimzada A, Bayen S, et al. Primary and secondary plastic particles exhibit limited acute toxicity but chronic effects on Daphnia magna. Environ Sci Technol. 2020;54(11):6859-68. https://doi.org/10.1021/acs.est.0c00245.

44. Schür C, Zipp S, Thalau T, Wagner M. Microplastics but not natural particles induce multigenerational effects in Daphnia magna. Environ Pollut. 2020; 260:113904. https://doi.org/10.1016/j.envpol.2019.113904.

45. Kokalj AJ, Hartmann NB, Drobne D, Potthoff A, Kühnel D. Quality of nanoplastics and microplastics ecotoxicity studies: refining quality criteria for nanomaterial studies. J Hazard Mater. 2021;415:125751. https://doi.org/10.1 016/j.jhazmat.2021.125751.

46. Lithner D, Nordensvan I, Dave G. Comparative acute toxicity of leachates from plastic products made of polypropylene, polyethylene, PVC, acrylonitrile-butadiene-styrene, and epoxy to Daphnia magna. Environ Sci Pollut Res. 2012;19(5):1763-72. https://doi.org/10.1007/s11356-011-0663-5.

47. Li HX, Getzinger GJ, Ferguson PL, Orihuela B, Zhu M, Rittschof D. Effects of toxic leachate from commercial plastics on larval survival and settlement of the barnacle Amphibalanus amphitrite. Environ Sci Technol. 2016;50(2):92431. https://doi.org/10.1021/acs.est.5b02781.

48. IL KJ, An YJ. Post COVID-19 pandemic: Biofragmentation and soil ecotoxicological effects of microplastics derived from face masks. J Hazard Mater. 2021;416:126169.

49. Au SY, Bruce TF, Bridges WC, Klaine SJ. Responses of Hyalella azteca to acute and chronic microplastic exposures. Environ Toxicol Chem. 2015; 34(11):2564-72. https://doi.org/10.1002/etc.3093.

50. Gray AD, Weinstein JE. Size- and shape-dependent effects of microplastic particles on adult daggerblade grass shrimp (Palaemonetes pugio). Environ Toxicol Chem. 2017:36(11):3074-80. https://doi.org/10.1002/etc.3881.

51. Duan Y, Xiong D, Wang Y, Zhang Z, Li H, Dong H, et al. Toxicological effects of microplastics in Litopenaeus vannamei as indicated by an integrated microbiome, proteomic and metabolomic approach. Sci Total Environ. 2021; 761:143311. https://doi.org/10.1016/j.scitotenv.2020.143311.

52. Welden NAC, Cowie PR. Long-term microplastic retention causes reduced body condition in the langoustine, Nephrops norvegicus. Environ Pollut. 2016;218:895-900. https://doi.org/10.1016/j.envpol.2016.08.020.

53. Horn DA, Granek EF, Steele CL. Effects of environmentally relevant concentrations of microplastic fibres on Pacific mole crab (Emerita analoga) mortality and reproduction. Limnol Oceanogr Lett. 2020;5(1):74-83. https:// doi.org/10.1002/lol2.10137.

54. Lei L, Wu S, Lu S, Liu M, Song Y, Fu Z, et al. Microplastic particles cause intestinal damage and other adverse effects in zebrafish Danio rerio and nematode Caenorhabditis elegans. Sci Total Environ. 2018;619-620:1-8. https://doi.org/10.1016/j.scitotenv.2017.11.103.

55. Kim SW, Waldman WR, Kim TY, Rillig MC. Effects of different microplastics on nematodes in the soil environment: tracking the extractable additives using an ecotoxicological approach. Environ Sci Technol. 2020;54(21):1386878. https://doi.org/10.1021/acs.est.0c04641.

56. Revel M, Yakovenko N, Caley T, Guillet C, Châtel A, Mouneyrac C. Accumulation and immunotoxicity of microplastics in the estuarine worm Hediste diversicolor in environmentally relevant conditions of exposure. 
Environ Sci Pollut Res. 2020;27(4):3574-83. https://doi.org/10.1007/s11356-01 8-3497-6.

57. Revel M, Châtel A, Perrein-Ettajani H, Bruneau M, Akcha F, Sussarellu R, et al. Realistic environmental exposure to microplastics does not induce biological effects in the Pacific oyster Crassostrea gigas. Mar Pollut Bull. 2020;150:110627. https://doi.org/10.1016/.marpolbul.2019.110627.

58. Revel M, Lagarde F, Perrein-Ettajani H, Bruneau M, Akcha F, Sussarellu R, et al. Tissue-specific biomarkeer responses in the blue mussel Mytilus spp. exposed to a mixture of microplastics at environmentally relevant concentrations. Front Environ Sci. 2019; doi:https://doi.org/10.3389/fenvs.201 9.00033 .

59. Phothakwanpracha J, Lirdwitayaprasit T, Pairohakul S. Effects of sizes and concentrations of different types of microplastics on bioaccumulation and lethality rate in the green mussel, Perna viridis. Mar Pollut Bull. 2021;173(Pt A):112954. https://doi.org/10.1016/j.marpolbul.2021.112954.

60. Tlili S, Jemai D, Brinis $S$, Regaya I. Microplastics mixture exposure at environmentally relevant conditions induce oxidative stress and neurotoxicity in the wedge clam Donax trunculus. Chemosphere. 2020;258: 127344. https://doi.org/10.1016/..chemosphere.2020.127344.

61. Khoironi A, Anggoro S. Evaluation of the interaction among microalgae Spirulina sp, plastics polyethylene terephthalate and polypropylene in freshwater environment. Ecological engineering. 2019; doi:https://doi.org/1 $0.12911 / 22998993 / 108637$.

62. Lagarde F, Olivier O, Zanella M, Daniel P, Hiard S, Caruso A. Microplastic interactions with freshwater microalgae: hetero-aggregation and changes in plastic density appear strongly dependent on polymer type. Environ Pollut. 2016;215:331-9. https://doi.org/10.1016/j.envpol.2016.05.006.

63. Wu Y, Guo P, Zhang X, Zhang Y, Xie S, Deng J. Effect of microplastics exposure on the photosynthesis system of freshwater algae. J Hazard Mater. 2019;374:219-27. https://doi.org/10.1016/j.jhazmat.2019.04.039.

64. Miloloža M, Bule K, Ukić Š, Cvetnić M, Bolanča T, Kušić H, et al. Ecotoxicological determination of microplastic toxicity on algae Chlorella sp.: response surface modeling approach. Water Air Soil Pollut. 2022;232:116.

65. Moreno GM, Cooper KR, Moreno GM, Cooper KR. Morphometric effects of various weathered and virgin/pure microplastics on sac fry zebrafish (Danio rerio). AlMS Environ Sci. 2021;8(3):204-20. https://doi.org/10.3934/ environsci.2021014.

66. Zhao Y, Qiao R, Zhang S, Wang G. Metabolomic profiling reveals the intestinal toxicity of different length of microplastic fibres on zebrafish (Danio rerio). J Hazard Mater. 2021;403:123663. https://doi.org/10.1016/j.jha zmat.2020.123663.

67. Sheng C, Zhang S, Zhang Y. The influence of different polymer types of microplastics on adsorption, accumulation, and toxicity of triclosan in zebrafish. J Hazard Mater. 2021;402:123733. https://doi.org/10.1016/j.jhazma t.2020.123733

68. Bucci K, Bikker J, Stevack K, Watson-Leung T, Rochman C. Impacts to larval fathead minnows vary between preconsumer and environmental microplastics. Environ Toxicol Chem 2021;00:0-1, DOl: https://doi.org/10.1 002/etc.5036.

69. Montero D, Rimoldi S, Torrecillas S, Rapp J, Moroni F, Herrera A, et al. Impact of polypropylene microplastics and chemical pollutants on European sea bass (Dicentrarchus labrax) gut microbiota and health. Sci Total Environ. 2022;805:150402. https://doi.org/10.1016/j.scitotenv.2021.150402.

70. Cheng $Y$, Song $W$, Tian $H$, Zhang $K, L i B, D u Z$, et al. The effects of highdensity polyethylene and polypropylene microplastics on the soil and earthworm Metaphire guillelmi gut microbiota. Chemosphere. 2021;267: 129219. https://doi.org/10.1016/j.chemosphere.2020.129219.

71. Li B, Song W, Cheng Y, Zhang K, Tian H, Du Z, et al. Ecotoxicological effects of different size ranges of industrial-grade polyethylene and polypropylene microplastics on earthworms Eisenia fetida. Sci Total Environ. 2021;783: 147007. https://doi.org/10.1016/j.scitotenv.2021.147007.

72. Zhou Y, Liu X, Wang J. Ecotoxicological effects of microplastics and cadmium on the earthworm Eisenia foetida. J Hazard Mater. 2020;392: 122273. https://doi.org/10.1016/j.jhazmat.2020.122273.

73. Amorim MJ, Scott-Fordsmand JJ. Plastic pollution-a case study with Enchytraeus crypticus-from micro-to nanoplastics. Environ Pollut. 2021;271: 116363. https://doi.org/10.1016/..envpol.2020.116363.

74. Zhong Z, Nong W, Xie Y, Hui JHL, Chu LM. Long-term effect of plastic feeding on growth and transcriptomic response of mealworms (Tenebrio molitor L.). Chemosphere. 2022;287(Pt 1):132063. https://doi.org/10.1016/j. chemosphere.2021.132063.

75. Pignattelli S, Broccoli A, Renzi M. Physiological responses of garden cress (L. sativum) to different types of microplastics. Sci Total Environ. 2020;727: 138609. https://doi.org/10.1016/j.scitotenv.2020.138609.

76. Colzi I, Renna L, Bianchi E, Castellani MB, Coppi A, Pignattelli S, et al. Impact of microplastics on growth, photosynthesis and essential elements in Cucurbita pepo L. J Hazard Mater. 2022;423(Pt B):127238. https://doi.org/10.1 016/j.jhazmat.2021.127238.

77. Peng L, Fu D, Qi H, Lan C, Yu H, Environment CG-S Of the T, et al. Microand nano-plastics in marine environment: source, distribution and threats—a review. Sci Total Environ. 2020;698:134254. https://doi.org/10.101 6/j.scitotenv.2019.134254.

78. Science Advice for Policy by European Academies (SAPEA). https://doi.org/1 0.26356/microplastics. Accessed 1 July 2021

79. Maity S, Pramanick K. Perspectives and challenges of micro/nanoplasticsinduced toxicity with special reference to phytotoxicity. Glob Change Biol. 2020;26(6):3241-50. https://doi.org/10.1111/gcb.15074.

80. PlasticsEurope. https://www.plasticseurope.org/en. Accessed 1 July 2021.

81. Statista. https://www.statista.com/statistics/1103529/global-polypropyleneproduction/. Accessed 1 July 2021.

82. Xu S, Ma J, Ji R, Pan K, Miao AJ. Microplastics in aquatic environments: occurrence, accumulation, and biological effects. Sci Total Environ. 2020;703: 134699. https://doi.org/10.1016/j.scitotenv.2019.134699.

83. Rochman CM, Brookson C, Bikker J, Djuric N, Earn A, Bucci K, et al. Rethinking microplastics as a diverse contaminant suite. Environ Toxicol Chem. 2019;38(4):703-11. https://doi.org/10.1002/etc.4371.

84. Ter Halle A, Ladirat L, Gendre X, Goudouneche D, Pusineri C, Routaboul C, et al. Understanding the fragmentation pattern of marine plastic debris. Environ Sci Technol. 2016;50(11):5668-75. https://doi.org/10.1021/acs.est. 6 b00594.

85. Wang $Q$, Zhang $Y$, Wangjin $X$, Wang $Y$, Meng $G$, Chen $Y$. The adsorption behavior of metals in aqueous solution by microplastics effected by UV radiation. J Environ Sci. 2020;87:272-80. https://doi.org/10.1016/j.jes.2019.07. 006.

86. Jemec Kokalj A, Kuehnel D, Puntar B, Žgajnar Gotvajn A, Kalčikova G. An exploratory ecotoxicity study of primary microplastics versus aged in natural waters and wastewaters. Environ Pollut. 2019;254(Pt A):112980. https://doi. org/10.1016/j.envpol.2019.112980

87. Kalčíková G, Skalar T, Marolt G, Jemec KA. An environmental concentration of aged microplastics with adsorbed silver significantly affects aquatic organisms. Water Res. 2020;175:115644. https://doi.org/10.1016/j.watres.202 0.115644 .

88. Liang W, Xu Y, Li X, Wang XX, Di Zhang H, Yu M, et al. Transparent polyurethane nanofibre air filter for high-efficiency PM2.5 capture. Nanoscale Res Lett. 2019:14:1-9.

89. Liu F, Li M, Shao W, Yue W, Hu B, Weng K, et al. Preparation of a polyurethane electret nanofibre membrane and its air-filtration performance. J Colloid Interface Sci. 2019;557:318-27. https://doi.org/10.101 6/j.jcis.2019.08.099.

90. Zhang Y, Yuan S, Feng X, Li H, Zhou J, Wang B. Preparation of nanofibrous metal-organic framework filters for efficient air pollution control. J Am Chem Soc. 2016;138(18):5785-8. https://doi.org/10.1021/jacs.6b02553.

91. Bondarenko O, Juganson K, Ivask A, Kasemets K, Mortimer M, Kahru A. Toxicity of ag, $\mathrm{CuO}$ and $\mathrm{ZnO}$ nanoparticles to selected environmentally relevant test organisms and mammalian cells in vitro: a critical review. Arch Toxicol. 2013;87(7):1181-200. https://doi.org/10.1007/s00204-013-1079-4.

\section{Publisher's Note}

Springer Nature remains neutral with regard to jurisdictional claims in published maps and institutional affiliations. 